Provided for non-commercial research and education use. Not for reproduction, distribution or commercial use.

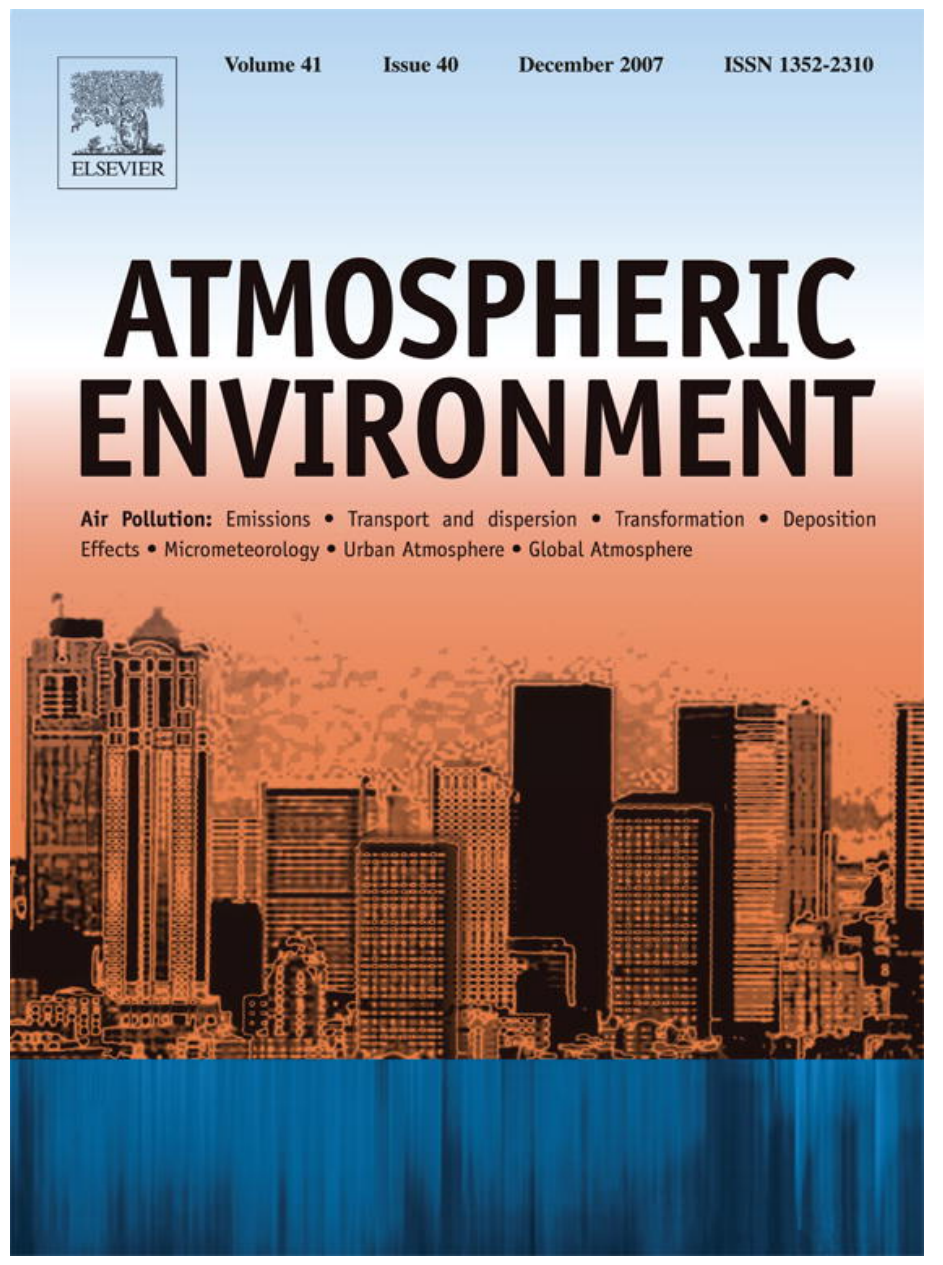

This article was published in an Elsevier journal. The attached copy

is furnished to the author for non-commercial research and education use, including for instruction at the author's institution, sharing with colleagues and providing to institution administration.

Other uses, including reproduction and distribution, or selling or licensing copies, or posting to personal, institutional or third party websites are prohibited.

In most cases authors are permitted to post their version of the article (e.g. in Word or Tex form) to their personal website or institutional repository. Authors requiring further information regarding Elsevier's archiving and manuscript policies are encouraged to visit: 


\title{
Photochemical production of ozone and control strategy for Southern Taiwan
}

\author{
Chein-Jung Shiu ${ }^{\mathrm{a}}$, Shaw Chen Liu ${ }^{\mathrm{a}, \mathrm{b}, *}$, Chih-Chung Chang ${ }^{\mathrm{b}}$, Jen-Ping Chen ${ }^{\mathrm{a}}$, \\ Charles C.K. Chou ${ }^{\mathrm{b}}$, Chuan-Yao Lin ${ }^{\mathrm{b}}$, Chea-Yuan Young ${ }^{\mathrm{c}}$ \\ ${ }^{a}$ Institute of Atmospheric Sciences, National Taiwan University, Taipei, Taiwan, ROC \\ ${ }^{\mathrm{b}}$ Research Center for Environmental Changes, Academia Sinica, No. 128, Sec. 2, Academia Road, Taipei 115, Taiwan, ROC \\ ${ }^{\mathrm{c}}$ Environmental Protection Administration, Taipei, Taiwan, ROC
}

Received 20 April 2007; received in revised form 30 July 2007; accepted 4 September 2007

\begin{abstract}
An observation-based method $(\mathrm{OBM})$ is developed to evaluate the ozone $\left(\mathrm{O}_{3}\right)$ production efficiency $\left(\mathrm{O}_{3}\right.$ molecules produced per $\mathrm{NO}_{x}$ molecule consumed) and $\mathrm{O}_{3}$ production rate $\left(P\left(\mathrm{O}_{3}\right)\right)$ during a field campaign in southern Taiwan. The method can also provide an estimate of the concentration of $\mathrm{OH}$. A key step in the method is to use observed concentrations of two aromatic hydrocarbons, namely ethylbenzene and $m, p$-xylene, to estimate the degree of photochemical processing and amounts of photochemically consumed $\mathrm{NO}_{x}$ and $\mathrm{NMHCs}$ by $\mathrm{OH}$. In addition, total oxidant $\left(\mathrm{O}_{3}+\mathrm{NO}_{2}\right)$ instead of $\mathrm{O}_{3}$ itself turns out to be very useful for representing ozone production in the OBM approach. The average $\mathrm{O}_{3}$ production efficiency during the field campaign in Fall (2003) is found to be about 10.2 \pm 3.9 . The relationship of $P\left(\mathrm{O}_{3}\right)$ with $\mathrm{NO}_{x}$ is examined and compared with a one-dimensional (1D) photochemical model. Values of $P\left(\mathrm{O}_{3}\right)$ derived from the OBM are slightly lower than those calculated in the 1D model. However, $\mathrm{OH}$ concentrations estimated by the OBM are about a factor of 2 lower than the 1D model. Fresh emissions, which affect the degree of photochemical processing appear to be a major cause of the underestimate. We have developed a three-dimensional (3D) $\mathrm{OBM} \mathrm{O}_{3}$ production diagram that resembles the EKMA ozone isopleth diagram to study the relationship of the total oxidant versus $\mathrm{O}_{3}$ precursors. The $3 \mathrm{D} \mathrm{OBM} \mathrm{O} \mathrm{O}_{3}$ production diagram suggests that reducing emissions of NMHCs are more effective in controlling $\mathrm{O}_{3}$ than reducing $\mathrm{NO}_{x}$. However, significant uncertainties remain in the OBM, and considerable more work is required to minimize these uncertainties before a definitive control strategy can be reached. The observationbased approach provides a good alternative to measuring peroxy radicals for evaluating the production of $\mathrm{O}_{3}$ and formulating $\mathrm{O}_{3}$ control strategy in urban and suburban environments.
\end{abstract}

(C) 2007 Elsevier Ltd. All rights reserved.

Keywords: Ozone; Precursors; Ozone production; Atmospheric oxidants; Ozone control strategy

\footnotetext{
*Corresponding author. Research Center for Environmental Changes, Academia Sinica, No. 128, Sec. 2, Academia Road, Taipei 115, Taiwan, ROC. Tel.: + 886226537303 ; fax: +886227880332 .

E-mail address: shawliu@rcec.sinica.edu.tw (S.C. Liu).
}

\section{Introduction}

Increases of tropospheric ozone $\left(\mathrm{O}_{3}\right)$ are a serious environmental concern because of their adverse impacts on human health, vegetation as well as their green house effect. Elevated $\mathrm{O}_{3}$ concentrations 
ranging from local to regional scales have been reported extensively (e.g., Lee et al., 1998; Oltmans et al., 1998; Jacob et al., 1999; Lin et al., 2000; Bronnimann et al., 2002; Akimoto, 2003; Lelieveld et al., 2004; Parrish et al., 2004; Jonson et al., 2005). For example, there is evidence of regional increase of $\mathrm{O}_{3}$ over East Asia in the range of 7-10 ppbv from 1970s to 1980s (Lee et al., 1998). In addition, the increase in Asian continental outflows was suggested to account for an increase of $\mathrm{O}_{3}$ in northern Pacific Ocean region (Parrish et al., 2004). Jacob et al. (1999) suggested that tripling Asian anthropogenic emissions from 1985 to 2010 would lead to an increase in monthly mean $\mathrm{O}_{3}$ concentration by 2-6ppbv in the western United States and by $1-3 \mathrm{ppbv}$ in the eastern US. Akimoto (2003) discussed that intercontinental transport of $\mathrm{O}_{3}$ and hemispheric $\mathrm{O}_{3}$ pollution would jeopardize agriculture and ecosystems worldwide and have a strong effect on climate. Both studies emphasize that international initiatives to mitigate global air pollution from both developed and developing countries are necessary.

Taiwan is located in the southern part of East Asia where the background $\mathrm{O}_{3}$ is influenced strongly by the outflow from Asian Continent in winter and spring. Taiwan itself also has had an extraordinary rapid economic development in the last few decades. Local photochemical production of $\mathrm{O}_{3}$ due to the large emissions of precursors plays a controlling role in the $\mathrm{O}_{3}$ distribution. According to Chou et al. (2006), the $\mathrm{O}_{3}$ concentration over Taiwan has increased consistently in the last 13 years, while other pollutants such as $\mathrm{SO}_{2}, \mathrm{NO}_{x}$ and PM10 have decreased. Their analysis suggested that the reduction in the titration effect of $\mathrm{NO}$ played an important role in the increase of $\mathrm{O}_{3}$ in urban areas. In addition, trends in photochemical production/ loss due to changes in local emission of $\mathrm{O}_{3}$ precursors as well as long-range transport also contribute to the trends of $\mathrm{O}_{3}$. The relationship between $\mathrm{O}_{3}$ and its precursors is important but complex. It affects trends of $\mathrm{O}_{3}$, more importantly, it is critical to the formulation of $\mathrm{O}_{3}$ control strategies. This work will focus on understanding the relationship between the production rate of $\mathrm{O}_{3}$ and its precursors.

Several approaches have been suggested for estimating the $\mathrm{O}_{3}$ production rate (Trainer et al., 2000). The most direct approach is to have measurements of concentrations of peroxy radicals, i.e. $\mathrm{HO}_{2}, \mathrm{R}_{i} \mathrm{O}_{2}$ and $\mathrm{NO}$ (Cantrell et al., 1996;
Mihelcic et al., 2003) and then apply the following equation to estimate gross production rate of $\mathrm{O}_{3}$ (Levy et al., 1985; Trainer et al., 1991), i.e.

$P_{\mathrm{g}}\left(\mathrm{O}_{x}\right)=[\mathrm{NO}]\left(\overline{k_{i}} \sum_{i}\left[\mathrm{R}_{i} \mathrm{O}_{2}\right]+k_{3}\left[\mathrm{HO}_{2}\right]\right)$,

where $P_{\mathrm{g}}\left(\mathrm{O}_{x}\right)$ denotes gross $\mathrm{O}_{x}$ production rate, $\mathrm{R}_{i} \mathrm{O}_{2}$ are alkyl peroxy radicals, $\overline{k_{i}}$ represents the average reaction rate constant for the reactions of $\mathrm{NO}$ with $\mathrm{R}_{i} \mathrm{O}_{2}$, and $k_{3}$ is the reaction rate constant for the reaction of $\mathrm{NO}$ with $\mathrm{HO}_{2}$. Other approaches estimate the peroxy radical concentration either from photo-stationary state assumption (Cantrell et al., 1993; Parrish et al., 1986) or from photochemical budget calculation (Kleinman, 1986; Kleinman et al., 2002a) and then use measured NO concentrations to derive $P_{\mathrm{g}}\left(\mathrm{O}_{3}\right)$. Still other approaches are based on photochemical model simulations that use the measured concentration of $\mathrm{NO}_{x}$ and VOCs to calculate the peroxy radical concentration (Mckeen et al., 1997; Frost et al., 1998). It is important to note that a straightforward photochemical representation of the production terms of $\mathrm{O}_{3}$ does not yield the simple expression in (1). To obtain Eq. (1), a "total oxidant" needs to be defined as suggested by Liu (1977) and Levy et al. (1985). There are various ways to define the total oxidant. A convenient and practical way is $\mathrm{O}_{x}=\mathrm{O}_{3}+\mathrm{NO}_{2}$, which is frequently used to study the $\mathrm{O}_{3}$ chemistry in local, regional and global scales (Logan, 1989; Sillman, 1999; Jacob, 1999; Finlayson-Pitts and Pitts, 2000; Molina and Molina, 2002; Kleinman et al., 2002b). A major advantage of this definition is that its production and loss are independent of the rapid photochemical reactions, which convert $\mathrm{O}_{3}$ to $\mathrm{NO}_{2}$ and vice versa. Since these reactions are fast in the urban and suburban atmosphere, bypassing them enable $P_{\mathrm{g}}\left(\mathrm{O}_{x}\right)$ to represent the real photochemical production of $\mathrm{O}_{3}$ better than $P_{\mathrm{g}}\left(\mathrm{O}_{3}\right)$.

In this study, two intensive field measurements in southern Taiwan are used in the OBM approach (Cardelino and Chameides, 2000) to estimate the production rate of $\mathrm{O}_{3}$. The major advantage of OBM is that it uses observations to constrain the model or the analysis, thus reducing some of the uncertainties in the model/analysis. We will also adopt the concept of $\mathrm{O}_{3}$ production efficiency suggested by Liu et al. (1987) and Trainer et al. (1993). It will become apparent later that our OBM approach consists primarily of observation-based 
analyses. The only modeling is a simple Lagrangian trajectory approach that is used to calculate photochemical oxidation rates of $\mathrm{VOC}$ and $\mathrm{NO}_{x}$ by $\mathrm{OH}$. Results of the OBM approach will be compared with previous studies as well as those simulated by a one-dimensional (1D) photochemical model. Actually, although to a much lesser extent, the 1D model is also an OBM because its emission rates of $\mathrm{NO}_{x}$ and $\mathrm{VOC}$ are constrained by fitting observed concentrations of $\mathrm{NO}_{x}$ and VOC in the surface layer. Detailed description of the measurements, methodology and the model is given in Section 2.

We will show that our OBM approach can provide valuable information for formulating $\mathrm{O}_{3}$ control strategies. It can also be used to estimate the concentration of $\mathrm{OH}$. Finally, because the approach is process-oriented, it is not location sensitive and thus can be readily applied to other regions.

\section{Measurements}

Two intensive field experiments were conducted by the Research Center for Environmental Changes (RCEC) of Academia Sinica in the KaohsiungPingtung (KaoPing) area in southern Taiwan during 26-29 September and 23-28 October 2003 (hereafter referred to as RCEC 2003 Experiment). Non- methane hydrocarbons (NMHCs) were collected daily with stainless canisters side by side with the air quality instruments at 12 Taiwan EPA (TEPA) air quality monitoring stations (as shown in Fig. 1) in two periods, namely 9-10 and 11-12 am, during the 10-day field campaign. The measurements between 11 and 12 am were intended to examine the NMHCs composition just before the peak of $\mathrm{O}_{3}$, which usually occurs between 12 and $1 \mathrm{pm}$. Measurements between 9 and $10 \mathrm{am}$ were designed to study the composition of NMHCs near the start of the daily photochemical cycle to get a measure of their $\mathrm{O}_{3}$ production potential for that day. The EPA monitoring stations have routine hourly measurements of $\mathrm{O}_{3}, \mathrm{CO}, \mathrm{NO}_{x}, \mathrm{SO}_{2}, \mathrm{PM} 10$ and meteorological parameters. Detailed sampling strategy and geographical information can be found in Chang et al. (2005).

Southern Taiwan centered around Kaohsiung urban center is a multi-town "mega-city" spanning over $30 \mathrm{~km} \times 50 \mathrm{~km}$ with more than six million inhabitants. Oxidants such as $\mathrm{O}_{3}$ and peroxyacetylnitrate (PAN) have become a serious environmental problem. In addition to large vehicle emissions, there are significant emission sources from four industrial parks nearby. During autumn and winter seasons when high-pressure conditions prevail, severe deteriorations of air quality with $\mathrm{O}_{3}$ over $120 \mathrm{ppbv}$ frequently occur in this region.

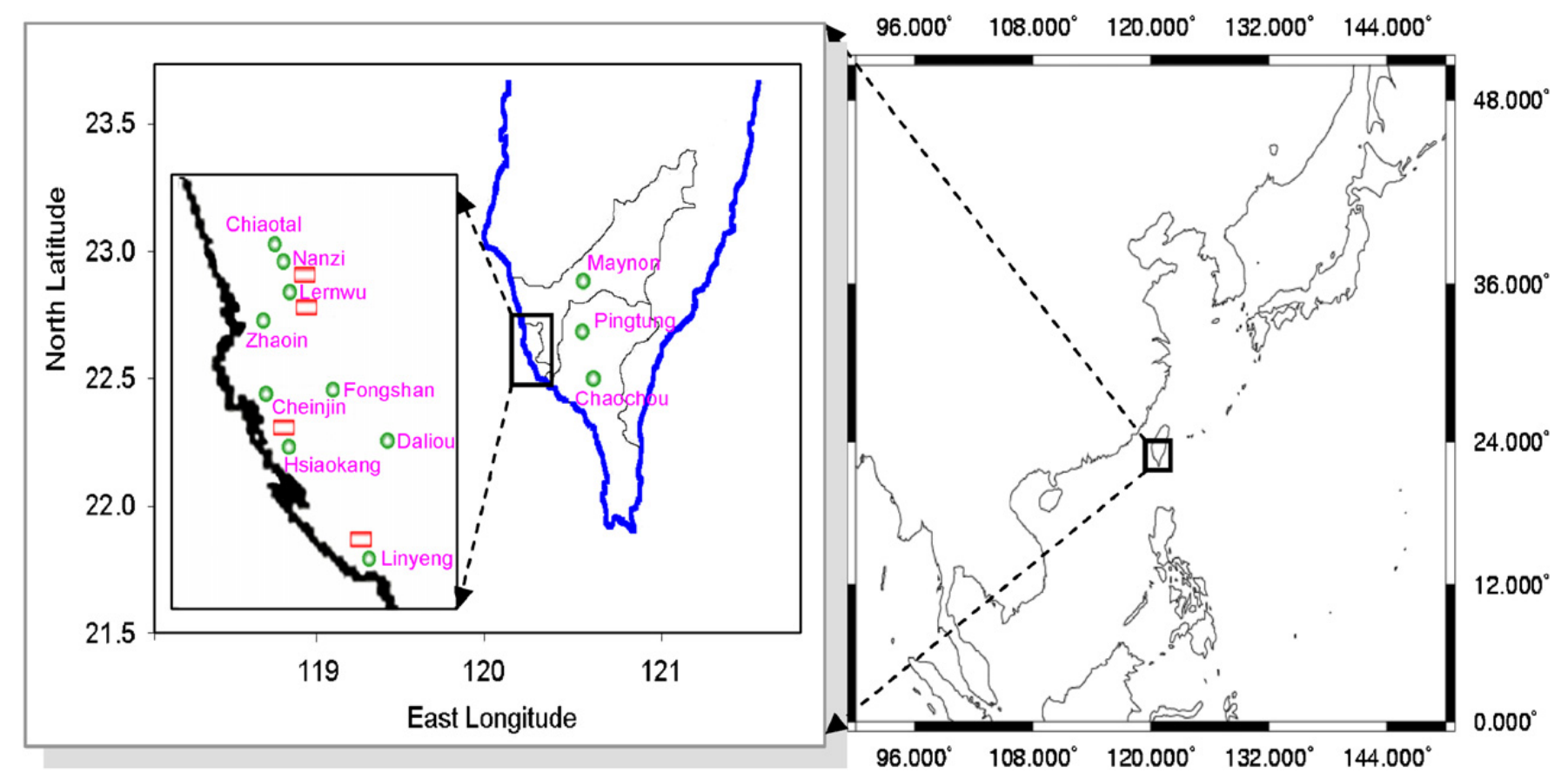

Fig. 1. Measurement stations of the intensive field experiments in southern Taiwan, East Asia. Solid circles represent the twelve Taiwan EPA air quality monitoring stations in Kaohsiung and Pingtung counties and the rectangles denote the four industrial parks in this region. 
$\mathrm{O}_{3}$ is measured using an ultra-violet photometric instrument with a precision of $1 \mathrm{ppbv}$. The oxides of nitrogen ( $\mathrm{NO}$ and $\mathrm{NO}_{2}$ ) are measured using a chemiluminescence instrument. The manufacturer suggested value of precision is 0.4 ppbv. However, our independent evaluation of the accuracy showed that the signal to noise level was about one at $3 \mathrm{ppbv}$ for NO, significantly worse than the manufacture suggested value (Chou et al., 2006). Similar accuracy was found for $\mathrm{NO}_{2}$. This can cause serious problem for $\mathrm{NO}$ measurements as $\mathrm{NO}$ values frequently dip below 5 ppbv during photochemically active hours. It is not a serious problem for $\mathrm{NO}_{2}$ because its values are usually greater than $10 \mathrm{ppbv}$. On the other hands, it is well known that the catalytic converter converting $\mathrm{NO}_{2}$ to $\mathrm{NO}$ suffers interference from none- $\mathrm{NO}_{2}$ compounds such as PAN and even $\mathrm{HNO}_{3}$. This problem will be elaborated later. A total of $56 \mathrm{C}_{2}-\mathrm{C}_{10}$ non-methane hydrocarbons were analyzed by a $\mathrm{GC} / \mathrm{MS}$ system. It is estimated that species not resolved by the GC/MS system are about $30-60 \%$ of the 56 NMHCs in terms of reactivity toward $\mathrm{OH}$ (Chang et al., 2003). Detailed description regarding the accuracy of the GC/MS instrument can be found in Chang et al. (2003).

\subsection{Meteorological conditions}

Meteorological parameters observed by the Central Weather Bureau station in Kaohsiung during the RCEC 2003 Experiment are shown in Fig. 2. Generally speaking, the weather was fair during the two field experiments and there was a typical land-sea breeze with westerly to northwesterly winds in the daytime and easterly to northeasterly winds at night. The diurnal variation of wind speed was consistent with the influence of land-sea breeze. The daytime maximum temperature during the 1 st periods of experiment (26-29 September 2003) was

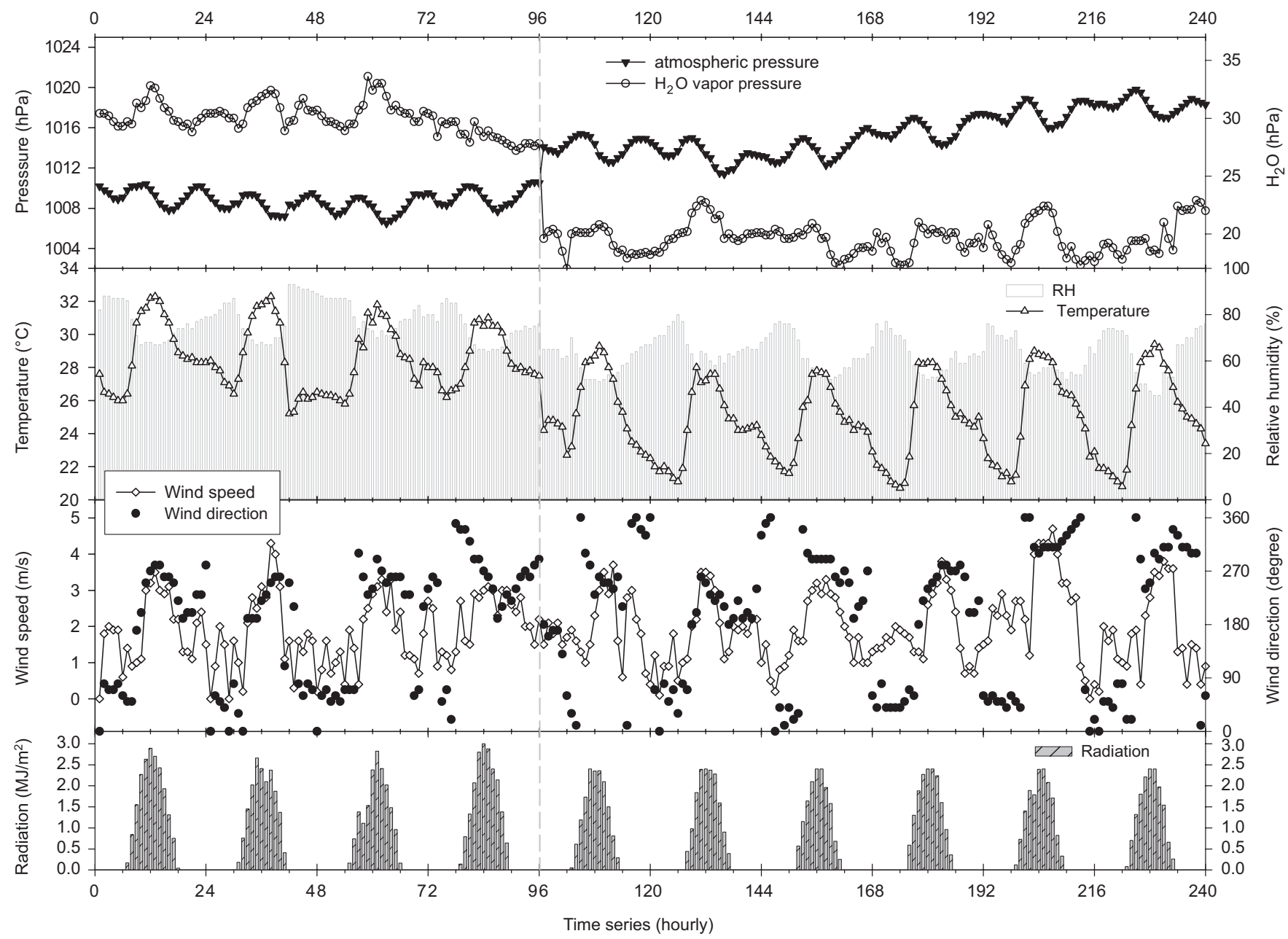

Fig. 2. Meteorological parameters observed during the 10-day intensive field experiments. The vertical dashed line in the figure is intended for separating the two periods of experiments (26-29 September and 23-28 October 2003). 
around $32^{\circ} \mathrm{C}$, and $28^{\circ} \mathrm{C}$ the 2 nd period $(23-28$ October 2003). The atmospheric moisture contents of 2 nd period were lower than those of 1 st period.

\subsection{Air quality during RCEC 2003 experiment}

Hourly time series of concentrations of $\mathrm{O}_{3}, \mathrm{NO}$, $\mathrm{NO}_{2}, \mathrm{CO}$ and PM10 for three EPA stations are shown in Fig. 3. Two urban stations, i.e. Lernwu and Zhaoin are located in the Kaohsiung city, while Chaochou is a suburban station in Pingtung County. The day-to-day variations of $\mathrm{O}_{3}$ for different stations show a similar pattern, but the primary pollutants like $\mathrm{CO}, \mathrm{NO}$ and $\mathrm{NO}_{2}$ distributions change greatly from station to station. Concentrations of $\mathrm{NO}, \mathrm{NO}_{2}$ and $\mathrm{CO}$ of Chaochou station are usually smaller than those of Lernwu and Zhaoin because of low industrial activities and smaller population density.

\subsection{Ozone production rate}

As mentioned earlier the derivation of $\mathrm{O}_{3}$ production efficiency follows the approach developed by Liu et al. (1987) and Trainer et al. (2000). The production rate of $\mathrm{O}_{3}, P\left(\mathrm{O}_{x}\right)$, can be expressed as

$$
\begin{aligned}
P\left(\mathrm{O}_{x}\right) & =\frac{\mathrm{d}\left[\mathrm{O}_{x}\right]}{\mathrm{d}\left[\mathrm{NO}_{x}\right]} \frac{\mathrm{d}\left[\mathrm{NO}_{x}\right]}{\mathrm{d} t} \approx \frac{\Delta\left[\mathrm{O}_{x}\right]}{\Delta\left[\mathrm{NO}_{x}\right]} \frac{\Delta\left[\mathrm{NO}_{x}\right]}{\Delta t} \\
& =\varepsilon \frac{\Delta\left[\mathrm{NO}_{x}\right]}{\Delta t},
\end{aligned}
$$

where $P\left(\mathrm{O}_{x}\right)$ is net $\mathrm{O}_{x}$ production, which is different from the gross $\mathrm{O}_{x}$ production $P_{\mathrm{g}}\left(\mathrm{O}_{x}\right)$ in Eq. (1).

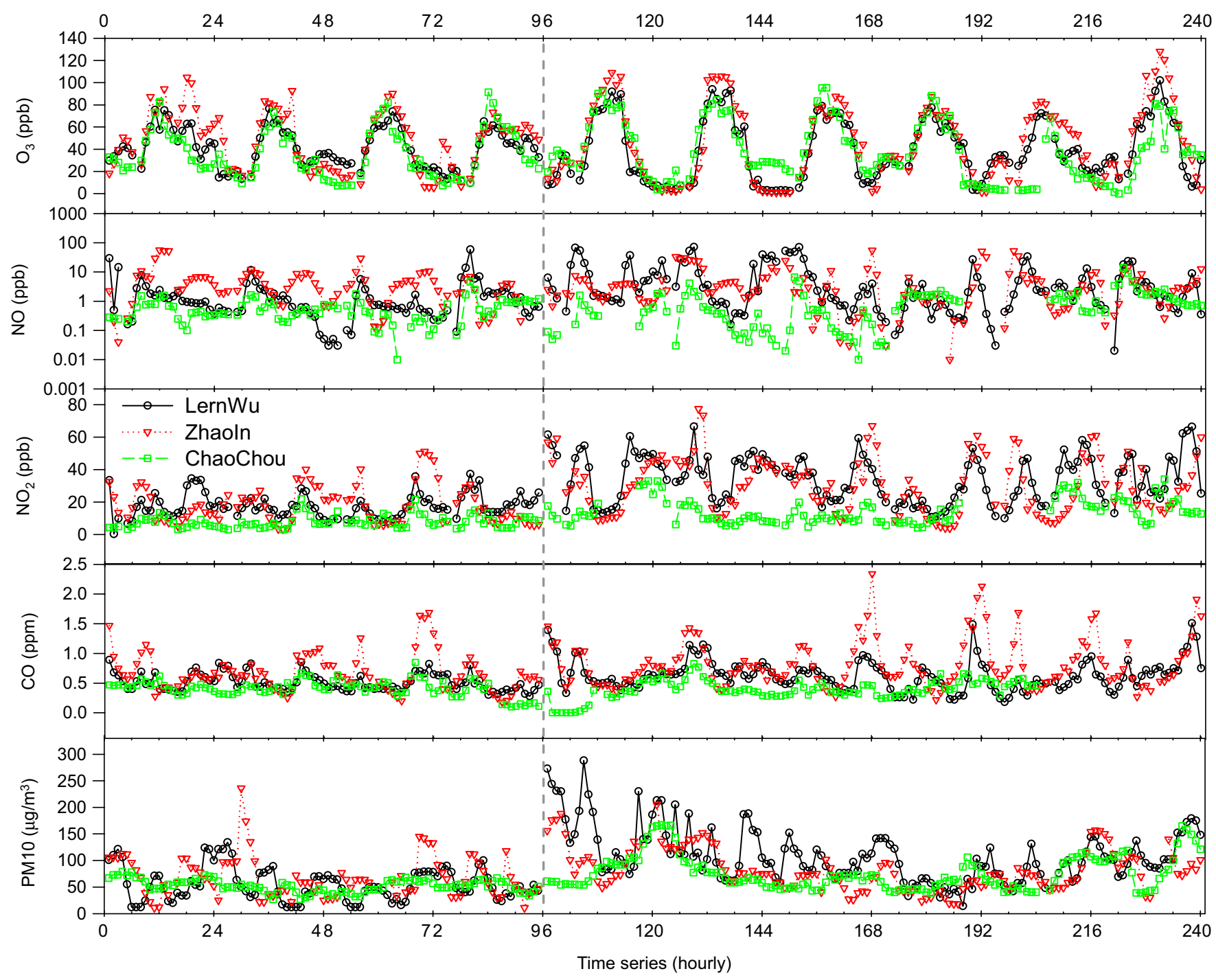

Fig. 3. Hourly time series of $\mathrm{O}_{3}, \mathrm{NO}, \mathrm{NO}_{2}, \mathrm{CO}$ and PM10 for the two experiments are shown in three different colors for three stations: Lernwu, Zhaoin and Chaochou. 
The net $\mathrm{O}_{x}$ production derived from observation of $\Delta\left[\mathrm{O}_{x}\right]$ is equal to the gross $\mathrm{O}_{x}$ production minus the gross photochemical loss, deposition and dispersion of $\mathrm{O}_{x}$.

$\varepsilon=\Delta\left[\mathrm{O}_{x}\right] / \Delta\left[\mathrm{NO}_{x}\right]$

is the $\mathrm{O}_{3}$ production efficiency. It is the number of $\mathrm{O}_{3}$ molecules produced per molecule of $\mathrm{NO}_{x}$ consumed photochemically (Liu et al., 1987; Trainer et al., 2000). Typical values of $\varepsilon$ over United States are in the range $1-20 \mathrm{~mol} \mathrm{~mol}^{-1}$ (Jacob, 1999). In the following, we use the data from field measurements to derive the $\mathrm{O}_{3}$ production efficiency, consumed $\mathrm{NO}_{x}$ (i.e. $\Delta\left[\mathrm{NO}_{x}\right]$ ) and $P\left(\mathrm{O}_{x}\right)$.

In the daytime, the major removal process of $\mathrm{NO}_{x}$ is the oxidation of $\mathrm{NO}_{2}$ by $\mathrm{OH}$ that produces $\mathrm{HNO}_{3} . \mathrm{HNO}_{3}$ is readily scavenged by gas-toparticle conversions, wash out or dry deposition. A minor sink of $\mathrm{NO}_{x}$ is the formation of PAN. However, PAN can undergo rapid thermal decomposition and regenerate $\mathrm{NO}_{x}$ at the prevailing temperature during the experiments. Nighttime reactions of $\mathrm{NO}_{3}$ and $\mathrm{N}_{2} \mathrm{O}_{5}$ are significant but neglected because the region studied in this work has substantial fresh emissions in the morning and we are mainly dealing with the production of $\mathrm{O}_{3}$ a few hours after the emissions of $\mathrm{O}_{3}$ precursors. Therefore, we consider reaction of $\mathrm{NO}_{2}$ with $\mathrm{OH}$ as the only removal process for $\mathrm{NO}_{x}$ and assume the removal of $\mathrm{NO}_{x}$ is pseudo-first order as shown below. In this case, following a Lagrangian trajectory, we have

$\left[\mathrm{NO}_{x}\right]=\left[\mathrm{NO}_{x}\right]_{0} \exp \left(-k \int_{0}^{t}[\mathrm{OH}] \mathrm{d} t\right)$,

where $k$ is the reaction rate constant of $\mathrm{NO}_{x}$ with $\mathrm{OH}$. The reaction rate constant for $\mathrm{NO}_{2}$ with $\mathrm{OH}$ is $1.04 \times 10^{-11} \mathrm{~cm}^{3} \mathrm{~s}^{-1}$ at $25^{\circ} \mathrm{C}$ and $1 \mathrm{~atm}$ pressure (Sander et al., 2002). Since $\mathrm{NO}_{2}$ is part of $\mathrm{NO}_{x}$, the value of $k$ should be scaled down by the ratio $\mathrm{NO}_{2} /$ $\mathrm{NO}_{x}$. The average of $\mathrm{NO}_{2} / \mathrm{NO}_{x}$ ratio is about 0.6, thus $k$ for $\mathrm{NO}_{x}$ is prescribed at $6.0 \times 10^{-12} \mathrm{~cm}^{3} \mathrm{~s}^{-1}$.

The ratio of two hydrocarbons that have same emission sources but different reactivities with $\mathrm{OH}$ can be used as a measure of photochemical oxidation by $\mathrm{OH}$ (Calvert, 1976; Singh, 1977; Robert et al., 1984; Parrish et al., 1992; Mckeen and Liu, 1993; Kramp and Volz-Thomas, 1997). We choose a pair of aromatic hydrocarbons, ethylbenzene and $m, p$-xylene, for this purpose (Chang et al., 2007). Again following the Lagrangian trajectory, we have

$E / X=\left(E_{0} / X_{0}\right) \exp \left(-\int_{0}^{t}\left(k_{\mathrm{e}}-k_{x}\right)[\mathrm{OH}] \mathrm{d} t\right)$,

where $E$ and $X$ represent concentrations of ethylbenzene and $m, p$-xylene at time $t$, respectively. $E_{0}$ and $X_{0}$ are their corresponding initial concentrations, $k_{x}$ and $k_{\mathrm{e}}$ their reaction rate constants with $\mathrm{OH}, \quad k_{x}$ and $k_{\mathrm{e}}$ equal to $2.17 \times 10^{-11}$ and $7.0 \times 10^{-12} \mathrm{~cm}^{3} \mathrm{~s}^{-1}$, respectively (Atkinson, 1990). The value of ratio $E_{0} / X_{0}$ is about 0.4 for the emission sources in southern Taiwan. This value is usually observed in the early morning around 7-8 am. In fact even around 9-10 am when we collect the first daily VOCs samples, the $E / X$ ratios were fairly close to 0.4 because the photochemical activities are relatively weak before $9-10 \mathrm{am}$. Using the observed value of $E / X$ at $11-12 \mathrm{am}, \int_{0}^{t}[\mathrm{OH}] \mathrm{d} t$ between early morning and 11-12am can be calculated from Eq. (5). Then using observed values of $\mathrm{NO}_{x}$ at $11-12 \mathrm{am}$, initial values of $\mathrm{NO}_{x}$ in the early morning (along the backward Lagrangian trajectory) can be calculated from Eq. (4), and the photochemically consumed values can be obtained from the difference between initial values and the values at 11-12 am. Similarly, NMHCs consumed by $\mathrm{OH}$ and initial values can be calculated from Eq. (6) (Chang et al., 2007).

$[\mathrm{NMHCs}]=[\mathrm{NMHCs}]_{0} \exp \left(-k_{i} \int_{0}^{t}[\mathrm{OH}] \mathrm{d} t\right)$,

where $k_{i}$ is the reaction rate constant of the individual NMHC reaction with $\mathrm{OH}$. It is important to note that any NMHCs derived from Eq. (6) along the backward Lagrangian trajectory, e.g. initial NMHCs and consumed NMHCs, are a sum of $\mathrm{OH}$ reactivity-weighted NMHCs, not a straight sum of NMHCs.

It should be noted that values calculated from Eqs. (4)-(6) so far do not need to know the time interval of $\int_{0}^{t}[\mathrm{OH}] \mathrm{d} t$. If one wants to derive the $\mathrm{OH}$ concentration, the time interval of the integration needs to be determined.

\subsection{D photochemical model}

The model is an updated version of the 1D photochemical model developed by Trainer et al. (1987, 1991). Photochemical mechanisms and reaction rate constants are updated following those in Wang et al. (2000). The vertical resolution of the model decreases from $2 \mathrm{~m}$ near the surface to $1 \mathrm{~km}$ 
at $12 \mathrm{~km}$ altitude. Species with a photochemical lifetime shorter than $10 \mathrm{~min}$ are calculated by neglecting the transport. The time step for model integration for transport and chemistry is $30 \mathrm{~s}$. Initial vertical distributions of trace species are prescribed by assuming constant mixing ratios equal to observed values in the mixed layer. The initial values of short-lived species in the mixed layer are not important to the model results because emissions and photochemistry quickly redefine the concentrations after a few days of model simulations. Above the mixed layer, mixing ratios of trace gases are assumed to be negligible except for $\mathrm{CO}$ and $\mathrm{O}_{3}$, which are assumed to be their observed seasonal average values. The value of eddy diffusion coefficient $\left(K_{\mathrm{z}}\right)$ in the surface layer is calculated from the similarity theory (Trainer et al., 1987). The value of $K_{\mathrm{z}}$ above the surface layer is specified to be $60 \mathrm{~m} \mathrm{~s}^{-2}$. Dry deposition and heterogeneous removal processes are included in the same way as Trainer et al. (1987). The surface resistance is set at $2 \mathrm{~s} \mathrm{~cm}^{-1}$ for $\mathrm{O}_{3}$ and peroxides, $0.1 \mathrm{~s} \mathrm{~cm}^{-1}$ for $\mathrm{HNO}_{3}$, and $3.3 \mathrm{~s} \mathrm{~cm}^{-1}$ for carbonyls and organic nitrates. Lifetimes of heterogeneous losses of soluble gases $\mathrm{HNO}_{3}, \mathrm{H}_{2} \mathrm{O}_{2}, \mathrm{ROOH}, \mathrm{CH} 3 \mathrm{OOH}, \mathrm{CH}_{2} \mathrm{O}, \mathrm{HCOOH}$, $\mathrm{CH}_{3} \mathrm{COOH}, \mathrm{SO}_{2}, \mathrm{SO}_{4}$ and CRESOL are assumed to be 5 days (Logan et al., 1981). Results of the layer of $16 \mathrm{~m}$ height at which most surface measurements were made are used to compare with measurements at surface stations and the OBM results.

The emission rates of $\mathrm{O}_{3}$ precursors are based on the Taiwan Emission Data System (TEDS 5.0, version of year 2000) published by the TEPA (http://www.aqmc.org.tw/). Area and line sources in the KaoPing area are averaged to obtain the average emission rates. The emission rates of $\mathrm{NO}_{x}$, $\mathrm{CO}$ and $\mathrm{SO}_{2}$ are assumed to be $3.4 \times 10^{16}$, $5.0 \times 10^{16}$, and $3.0 \times 10^{15}$ molecules $\mathrm{m}^{-2} \mathrm{~s}^{-1}$, respectively. The emission rates of ethane, propane, butane, ethane, propene and toluene were assumed to be $3.4 \times 10^{15}, 2.5 \times 10^{15}, 2.7 \times 10^{15}, 5.9 \times 10^{15}$, $8.4 \times 10^{15}$ and $2.6 \times 10^{15}$ molecules $\mathrm{m}^{-2} \mathrm{~s}^{-1}$, respectively. Emission rates of $\mathrm{NO}_{x}$ and NMHCs are then tuned into the diurnal emission rates by multiplying a diurnal variation factor (from 6 to $5 \mathrm{am}$ : 1.0, 1.3, $2.8,1.2,0.9,0.8,0.7,0.7,0.7,0.7,0.7,0.6,0.6,0.6$, $0.6,0.6,0.5,0.5,0.5,0.5,0.5,0.5,0.6,0.8)$. Isoprene emission rate is fixed at $3.6 \times 10^{15}$ molecules $\mathrm{m}^{-2} \mathrm{~s}^{-1}$. The solar zenith angle is set to be that of 30 September 2003 for $22.5^{\circ} \mathrm{N}$. The photo-dissociation rate constants are generated by Tropospheric Ultra-Violet (TUV) Radiation model (TUV 4.2;
Madronich and Flocke, 1998). The climatological values of total $\mathrm{O}_{3}$ observed by Brewer ozone-meter at Chengkung station $\left(121.3^{\circ} \mathrm{E}, 23.1^{\circ} \mathrm{N}\right.$, close to the latitude of northern Kaohsiung county) and aerosol optical depth of 0.4 at $550 \mathrm{~nm}$ are used. The model calculation is carried out for 3 days to reach a quasi-steady-state condition. Atmospheric concentrations at 11-12 am of day 4 simulation are used to compare with the OBM results.

\section{Results and discussion}

\subsection{Ozone production efficiency}

$\Delta\left[\mathrm{O}_{x}\right]$ in Eq. (3) for calculating the $\mathrm{O}_{3}$ production efficiency can be calculated from observed $\mathrm{O}_{3}+\mathrm{NO}_{2}$ at 11-12 am minus the concentration of $\mathrm{O}_{3}+\mathrm{NO}_{2}$ observed at 9-10 am. This assumes that the increase in $\mathrm{O}_{x}$ from $9-10$ to $11-12 \mathrm{am}$ is equal to the photochemical production of $\mathrm{O}_{x}$. In reality, we know that part of the increase in $\mathrm{O}_{3}$ is the result of downward transport of $\mathrm{O}_{3}$ above the inversion layer, which is $\mathrm{O}_{3}$ leftover from the previous day. We estimate that the downward transport is insignificant after $10 \mathrm{am}$ and is compensated in part by the loss and dispersion of $\mathrm{O}_{x}$ near $12 \mathrm{am}$ when peak $\mathrm{O}_{x}$ is approached. Dilution effect of $\mathrm{O}_{x}$ due to the growth of the mixed layer is also a concern. A major reason the late morning is chosen to make the OBM study is to avoid the dilution effect. Diurnal variations of trace species such as $\mathrm{CO}$ and long-lived NMHCs in the morning can give a good measure of the dilution effect. Decreases of $\mathrm{CO}$ and long-lived NMHCs between 8 and 10 am range from $30 \%$ to $50 \%$, but only $15 \%$ to $25 \%$ between 10 and $12 \mathrm{am}$. Surely dilution of short-lived species like $\mathrm{NO}_{x}$ should be higher than $\mathrm{CO}$ because the air above the mixed layer contains negligible $\mathrm{NO}_{x}$. Observed decreases of $\mathrm{NO}_{x}$ is about a factor of 1.3 greater than the decrease of $\mathrm{CO}$, but part of that is due to greater photochemical loss of $\mathrm{NO}_{x}$ between 10 to $12 \mathrm{am}$.

$\Delta \mathrm{NO}_{x}$ in Eq. (3) should be the $\mathrm{NO}_{x}$ consumed by $\mathrm{OH}$ between 9-10 and 11-12 am at each station. The $\mathrm{NO}_{x}$ consumed between 11 and $12 \mathrm{am}$ and early morning can be calculated from Eq. (4), using $\int_{0}^{t}[\mathrm{OH}] \mathrm{d} t$ from Eq. (5), similarly for the $\mathrm{NO}_{x}$ consumed between 9 and $10 \mathrm{am}$ and sunrise. However, $\Delta \mathrm{NO}_{x}$ does not equal to the difference between the above two values, because the consumed $\mathrm{NO}_{x}$ at a station between a time and sunrise is a quantity calculated along the Lagrangian 
trajectory, which does not necessarily pass over the same station at an earlier time. Instead we calculate $\Delta \mathrm{NO}_{x}$ by assuming the consumed $\mathrm{NO}_{x}$ at different time interval is proportional to the UV dosage in each interval, i.e. we multiply the $\mathrm{NO}_{x}$ consumed between 11 and $12 \mathrm{am}$ and sunrise by the fraction of solar UV radiation between 9-10 and 11-12 am. $\Delta \mathrm{NO}_{x}$ calculated this way is plotted against $\Delta \mathrm{O}_{x}$ calculated in Fig. 4.

Each data points in Fig. 4 can yield a value for $\Delta \mathrm{O}_{x} / \Delta \mathrm{NO}_{x}$, i.e. the $\mathrm{O}_{3}$ production efficiency ( $(\varepsilon)$. Because the data are from 12 stations, the scattered distribution of Fig. 4 is expected. Values calculated from the 1D model is shown by the solid line. The agreement with the linear fit line is reasonably good. The equivalent plot for NHMCs can be seen in Fig. 5. $\triangle \mathrm{NMHC}$ of the figure is calculated individually from Eq. (6), i.e. each of the 56 identified NMHCs is treated the same way as $\mathrm{NO}_{x}$ in calculating $\Delta \mathrm{NO}_{x}$. If the consumption of $\mathrm{CO}$ and $\mathrm{CH}_{4}$ were also added to the consumption of NMHCs, the $R^{2}$ for $\Delta \mathrm{O}_{x}$ vs. $\Delta \mathrm{NMHCs}+\Delta \mathrm{CO}+$ $\Delta \mathrm{CH}_{4}$ would be improved a little more $\left(R^{2}=0.68\right.$, not shown). It is interesting to note that the $R^{2}$ of $\Delta \mathrm{O}_{3}$ vs. $\triangle \mathrm{NMHCs}$ is greater than that for $\Delta \mathrm{O}_{3}$ vs. $\Delta \mathrm{NO}_{x}$, suggesting that $\mathrm{O}_{3}$ production in KaoPing area is more closely related with the consumed NMHCs than the consumed $\mathrm{NO}_{x}$. Nevertheless we

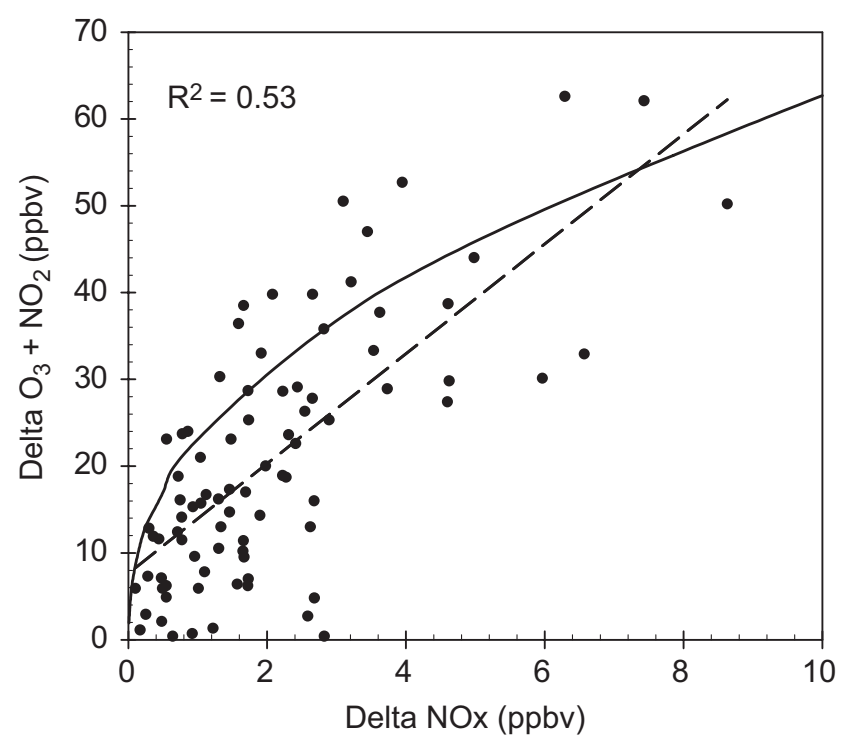

Fig. 4. $\Delta\left[\mathrm{O}_{3}+\mathrm{NO}_{2}\right]$, i.e. difference between $\left[\mathrm{O}_{3}+\mathrm{NO}_{2}\right]$ at 11-12 am and that at $9-10 \mathrm{am}$, is plotted as a function of the $\mathrm{NO}_{x}$ consumed by $\mathrm{OH}$ between $9-10$ and $11-12$ am, i.e. $\Delta \mathrm{NO}_{x}$. The dashed line is the linear regression line for all points, and $R^{2}$ is the coefficient of determination. Values simulated by the $1 \mathrm{D}$ model are shown in solid line.

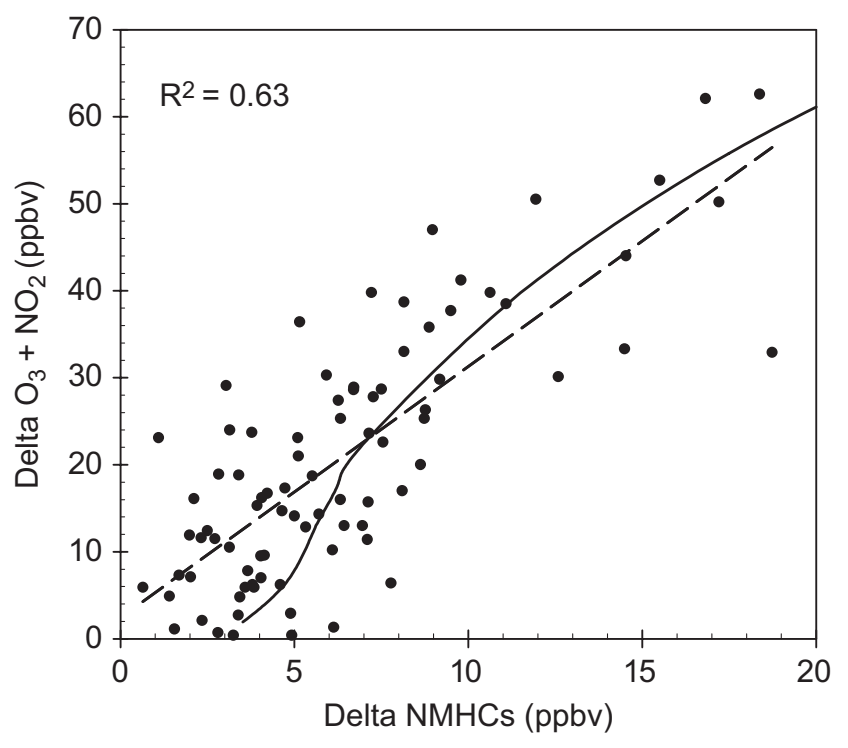

Fig. 5. Same as Fig. 4 except the horizontal axis is changed to $\triangle$ NNHCs.

note that $\mathrm{NO}_{x}$ is also correlated with NMHCs as the two $\mathrm{O}_{3}$ precursors share a major common source, namely the vehicular emissions. This means that NMHCs and $\mathrm{NO}_{x}$ cannot be treated as independent variables and the correlations shown in Figs. 4 and 5 need to be interpreted with caution.

We examined the corresponding plots of Figs. 4 and 5 for each station in KaoPing area and found that 9 out of 12 stations have $R^{2}>0.5$ and up to 0.9 for $\Delta \mathrm{O}_{x}$ versus $\Delta \mathrm{NO}_{x}$ (not shown). Furthermore, $R^{2}$ for $\Delta \mathrm{O}_{x}$ versus consumed NMHCs usually are higher than those of $\Delta \mathrm{O}_{x}$ versus consumed $\mathrm{NO}_{x}$ (not shown). After inspecting the diurnal variation of $\mathrm{NO}_{x}, \mathrm{CO}$ and $\mathrm{O}_{3}$ of the 12 stations, we found that the three stations with exceptional low $R^{2}$ values are mostly affected by significant fresh missions at 11-12 am. Fresh emissions also contribute significantly to many points that have very low values of consumed $\mathrm{NO}_{x}$. Strictly speaking, all surface stations are affected to certain degree by fresh emissions. The fresh emissions can be detected by large ratio of isobutene to ethane because the former has relatively short lifetime compared with that of ethane. Significant fresh emissions at 11-12 am can introduce a significant error in Eq. (5) and result in under-estimating the photochemical activity. The error can result in an unreasonably large value of $\varepsilon$ because of an erroneous small consumed $\mathrm{NO}_{x}$ in the denominator. In order to screen out the bias due to significant fresh emissions, we exclude the points with ratio of 
isobutene to ethane greater than 0.2 . Values of $\varepsilon$ calculated this way are shown in open circles in Fig. 6 as a function of the observed $\mathrm{NO}_{x}$.

An independent method to estimate the $\mathrm{O}_{3}$ production efficiency was given in a simple analytical formula by Jacob (1999):

$\varepsilon=\frac{P_{\mathrm{g}}\left(\mathrm{O}_{x}\right)}{L\left(\mathrm{NO}_{x}\right)} \approx \frac{\sum_{i}^{n} 2 k_{i}\left[\mathrm{RH}_{i}\right]}{k\left[\mathrm{NO}_{2}\right]}$,

where $L\left(\mathrm{NO}_{x}\right)$ is the loss rate of $\mathrm{NO}_{x}, \mathrm{P}_{\mathrm{g}}\left(\mathrm{O}_{x}\right)$ the gross $\mathrm{O}_{x}$ production, $\left[\mathrm{RH}_{i}\right]$ is the concentration of $i$ th hydrocarbon and $k_{i}$ are the corresponding reaction rate constants for reacting of $\mathrm{RH}_{i}$ with $\mathrm{OH}$, and the " $k$ " in $k\left[\mathrm{NO}_{2}\right]$ is the reaction rate
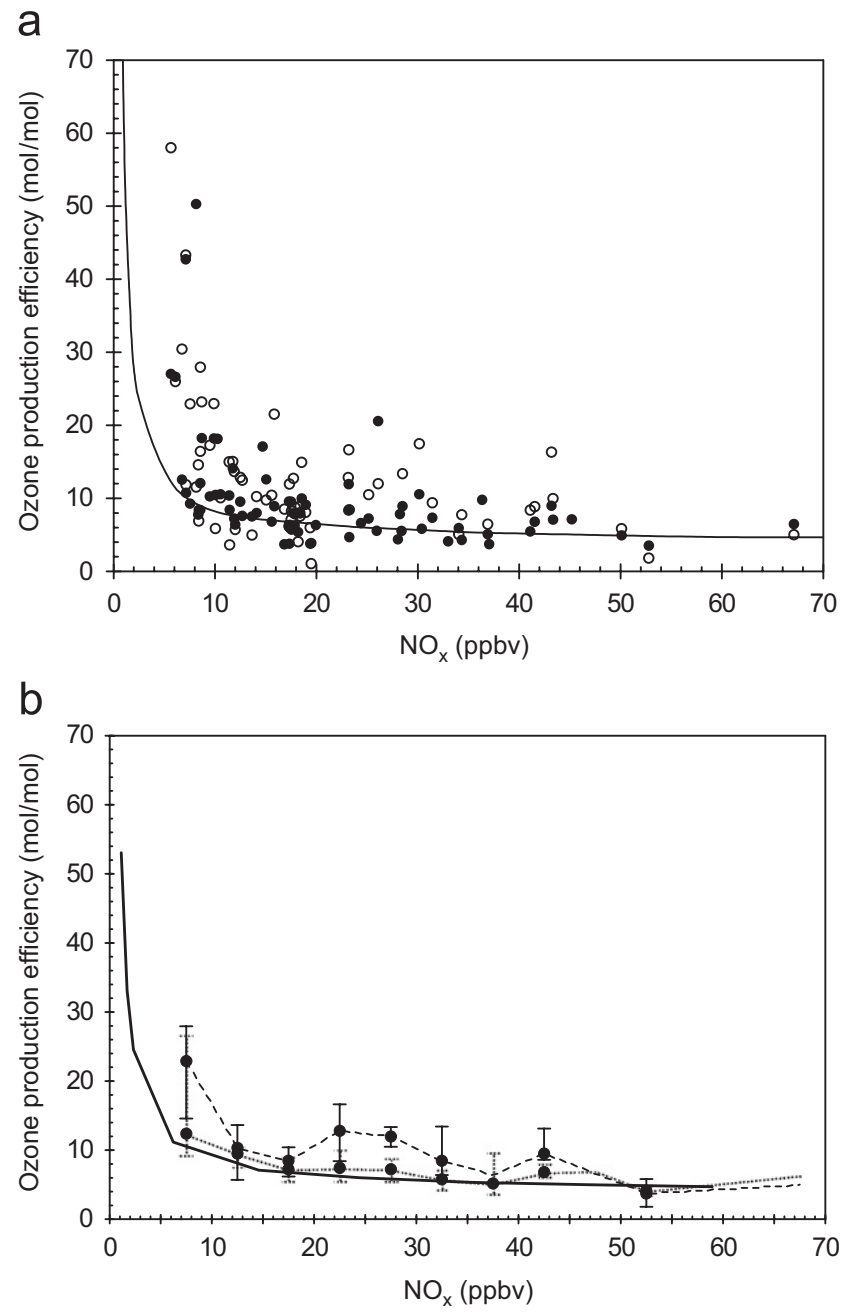

Fig. 6. (a) Total oxidant production efficiency calculated from Eq. (7) (solid circles) and from the OBM or Eq. (2) (open circles) are plotted as a function of $\mathrm{NO}_{x}$ concentration. Also shown is the total oxidant production efficiency simulated by the 1D model (solid line). (b) Similar to (a) but data are shown in median values (dotted and dashed lines) and 75 percentile (vertical bars), dotted line is from Eq. (7) and dashed line is from the OBM or Eq. (2). constant for $\mathrm{NO}_{2}+\mathrm{OH} \rightarrow \mathrm{HNO}_{3}$. According to the $1 \mathrm{D}$ model, $P_{\mathrm{g}}\left(\mathrm{O}_{x}\right)$ is about $20 \%$ greater than the net $\mathrm{O}_{x}$ production $P\left(\mathrm{O}_{x}\right)$ at $10-12 \mathrm{am}$. The gross $\mathrm{O}_{x}$ loss is about $15 \%$ of $P_{\mathrm{g}}\left(\mathrm{O}_{x}\right)$, while dry deposition and dispersion of $\mathrm{O}_{x}$ is estimated to be about $5 \%$ of $P_{\mathrm{g}}\left(\mathrm{O}_{x}\right)$.

Consumed $\mathrm{NO}_{x}$ and NMHCs between 10 and $12 \mathrm{am}$, which are consistent with Jacob's formulation are used in calculating Eq. (7). Also, an adjustment factor 1.5 is multiplied to the 56 NMHCs to account for the unresolved NMHCs. Eq. (7) is similar to the $\mathrm{O}_{3}$ production efficiency derived by Kleinman et al. (2002b) except that an $\mathrm{O}_{3}$ yield resulting from the production of peroxy radicals are simplified to a constant i.e. 2 . The values of $\varepsilon$ as a function of $\mathrm{NO}_{x}$ derived for the 12 stations in KaoPing area for 11-12 am are shown in solid circles in Fig. 6a. The distribution of $\varepsilon$ as a function of $\mathrm{NO}_{x}$ and the regression line for 9-10 am (not shown here) are similar with those for 11-12 am. One can see that the OBM method and the Jacob equation are in good agreement, albeit the OBM values have rather large scattering. The median and 75 percentile of the OBM values are $23.5 \pm 7.3 \mathrm{~mol} \mathrm{~mol}^{-1}$ at $\mathrm{NO}_{x} \leqslant 10 \mathrm{ppbv}$, and converges to $8.6 \pm 3.5$ for $\mathrm{NO}_{x} \gg 20$ ppbv (Fig. $6 \mathrm{~b}$ ). The median and 75 percentile of values from the Jacob method are $12.5 \pm 6.1 \mathrm{~mol} / \mathrm{mol}$ at $\mathrm{NO}_{x} \leqslant 10 \mathrm{ppbv}$, and converges to $6.4 \pm 1.3$ for $\mathrm{NO}_{x} \gg 20 \mathrm{ppbv}$ (Fig. 6b). The values of $\varepsilon$ from the 1D model are slightly smaller than both OBM and Jacob method for $\mathrm{NO}_{x}$ greater than 10 ppbv. But at lower $\mathrm{NO}_{x}$ the $\mathrm{OBM}$ values are about two times higher than the 1D model.

Both methods show that $\varepsilon$ increases with decreasing $\mathrm{NO}_{x}$. This implies that the $\mathrm{O}_{3}$ production efficiency is greater when $\mathrm{O}_{3}$ precursors are diluted and diffused. E.g. $\varepsilon$ tends to be greater in rural and suburban conditions than the highly polluted urban conditions. This is consistent with earlier works (Liu et al., 1987; Kleinman et al., 2002b; Zaveri et al., 2003). $\varepsilon$ approaches a constant average value of about 5-8 (as shown by the regression curves) when $\mathrm{NO}_{x}$ is higher than 10 ppbv. Sillman et al. (1998), Nunnermacker et al. (1998), Ryerson et al. (1998) and Daum et al. (2000) all found $\varepsilon$ values from 3 to 5 at $\mathrm{NO}_{x}$ concentrations of urban level, derived from both models and measurements. Others (Chin et al., 1994; Olszyna et al., 1994; Trainer et al., 1995) estimates about $1.5-10$ for rural and regional environments. These values are about a factor of two to three less than our values. An obvious reason 
for our over-estimate of $\varepsilon$ is that our estimate is derived in the ambient environment near noontime, i.e. around peak $\mathrm{O}_{3}$ production time. Since the nighttime loss of $\mathrm{NO}_{x}$ through $\mathrm{NO}_{3}$ and $\mathrm{N}_{2} \mathrm{O}_{5}$ can contribute up to $40 \%$ of the total loss of $\mathrm{NO}_{x}$, our $\varepsilon$ value should be about $60 \%$ higher than diurnal average values for this reason alone. Possible loss of $\mathrm{NO}_{x}$ through PAN, other organic nitrates, and even HONO, which are not included in our calculation of $\varepsilon$ can also contribute significantly to the overestimate.

\subsection{Ozone production rate}

Values of the $\mathrm{O}_{3}$ production rate, $P\left(\mathrm{O}_{x}\right)$, derived from Eq. (2) are shown as a function of $\mathrm{NO}_{x}$

a

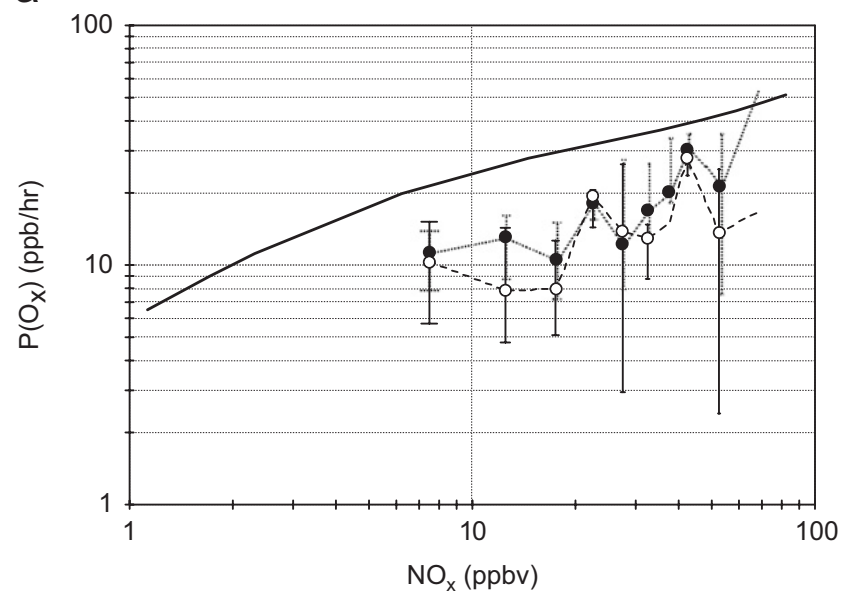

b

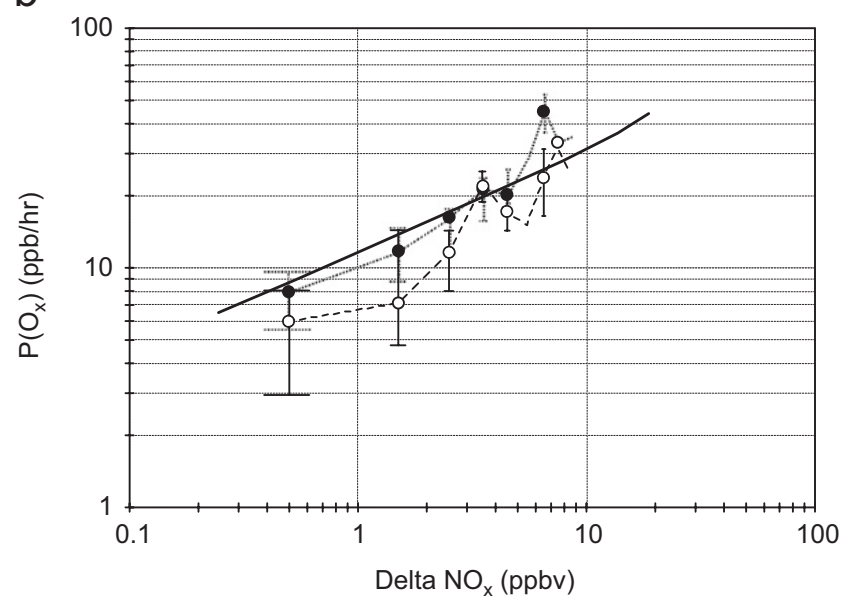

Fig. 7. (a) Median values and 75 percentile of total oxidant production rate derived from Eq. (7) (dotted line and bars) and from the OBM or Eq. (2) (dashed line and bars) are plotted as a function of the $\mathrm{NO}_{x}$ concentration. Also shown is ozone production rate calculated by the $1 \mathrm{D}$ model (solid line). (b) Same as (a) but plotted as a function of $\Delta \mathrm{NO}_{x}$. concentration in Fig. 7. OBM-based $P\left(\mathrm{O}_{x}\right)$ in KaoPing area can range from a few to $10 \mathrm{ppbvh}^{-1}$ when $\mathrm{NO}_{x}$ concentration is less than 10 ppbv. When $\mathrm{NO}_{x}$ concentration is increased to $30 \mathrm{ppbv}, P\left(\mathrm{O}_{x}\right)$ can be as large as $30 \mathrm{ppbvh}^{-1}$. Because the data for OBM are from 12 different sites in KaoPing area that include upwind, urban center and downwind sites, the scattered distribution of $P\left(\mathrm{O}_{x}\right)$ vs. $\mathrm{NO}_{x}$ is expected. $P\left(\mathrm{O}_{x}\right)$ can also be calculated from the Jacob equation. Values of $\mathrm{P}\left(\mathrm{O}_{x}\right)$ from this method agree very well with those of OBM approach. There are some outliers estimated by the OBM with low values less than $2 \mathrm{ppbvh}^{-1}$. As discussed earlier, they are likely the result of fresh emissions.

Also shown in Fig. 7a are the model simulated $P\left(\mathrm{O}_{x}\right)$ versus $\mathrm{NO}_{x}$. The median values of $P\left(\mathrm{O}_{x}\right)$ obtained by OBM and the Jacob equation are about $60 \%$ and $40 \%$ smaller than model simulated values, respectively.

We have compared our values of $P\left(\mathrm{O}_{x}\right)$ from OBM with those derived by Frost et al. (1998). Unfortunately our values are at much higher concentrations of $\mathrm{NO}_{x}$ than Frost et al. (1998) as theirs are aircraft measurements while ours are from surface stations in urban and suburban areas in the morning between 9-10 and $11-12 \mathrm{am}$. It is well known that the top of the mixed layer usually grows in the morning and does not reach the top of the boundary layer of the previous day $(\sim 1.5 \mathrm{~km})$ until about noontime. As a result, surface stations tend to be influenced by fresh emissions significantly in the morning. This is evident by the observed decreasing concentrations of $\mathrm{CO}, \mathrm{NO}_{x}$ and NMHCs in the morning at nearly all stations. Part of the decreases of $\mathrm{NO}_{x}$ and NMHCs is due to photochemical consumption, the decrease of $\mathrm{CO}$ is due to the dilution of fresh emissions when the mixed layer grows in thickness.

$P\left(\mathrm{O}_{x}\right)$ simulated by our 1D model is very similar to that of Frost et al. (1998) below a few ppbv of $\mathrm{NO}_{x}$. Above a few ppbv of $\mathrm{NO}_{x}, P\left(\mathrm{O}_{x}\right)$ in the model of Frost et al. (1998) levels off and starts to decrease, while $P\left(\mathrm{O}_{x}\right)$ in our model continue to increase with $\mathrm{NO}_{x}$ (Fig. 7a). One reason for the difference is that their NMHC mix has significant higher isoprene, which does not increase with $\mathrm{NO}_{x}$. Another reason is probably because we have a more reactive mix of NMHCs. In this context, we note that Kleinman et al. (2002a) compared $P\left(\mathrm{O}_{x}\right)$ vs. $\mathrm{NO}_{x}$ in 5 urban areas in the United States and found that the peak $P\left(\mathrm{O}_{x}\right)$ occurred at $\mathrm{NO}_{x}$ concentration of about few to $20 \mathrm{ppbv}$ for those 
cities. In very polluted site, the $P\left(\mathrm{O}_{x}\right)$ was larger than $30 \mathrm{ppbv} \mathrm{h}^{-1}$ and the decreasing values of $P\left(\mathrm{O}_{x}\right)$ with increasing $\mathrm{NO}_{x}$ was not observed, consistent with results of our 1D model and the OBM.

From the discussion on the $\mathrm{O}_{3}$ production efficiency, it is clear that $P\left(\mathrm{O}_{x}\right)$ should be related to the consumed $\mathrm{NO}_{x}$ better than $\mathrm{NO}_{x}$ itself. In Fig. $7 \mathrm{~b}, P\left(\mathrm{O}_{x}\right)$ is plotted against $\Delta \mathrm{NO}_{x}$, the consumed $\mathrm{NO}_{x}$ between 9-10 and 11-12 am. As expected the correlation of $P\left(\mathrm{O}_{x}\right)$ with $\Delta \mathrm{NO}_{x}$ improved significantly because $\Delta \mathrm{NO}_{x}$ is a better measure of the photochemical activity. Values of $P\left(\mathrm{O}_{x}\right)$ from the OBM agree well with those from the $1 \mathrm{D}$ model at $\Delta \mathrm{NO}_{x}>3 \mathrm{ppbv}$. Below $3 \mathrm{ppbv}$ of $\Delta \mathrm{NO}_{x}$, values of $P\left(\mathrm{O}_{x}\right)$ from OBM are about $50 \%$ lower. Consider the uncertainties involved in all three methods, the discrepancies are surprisingly small. In fact, the good agreement between the 1D model and Jacob's approach is likely to be fortuitous as the latter is the gross photochemical production of $\mathrm{O}_{x}$, while the former is the net $\mathrm{O}_{x}$ photochemical production. The OBM values are expected to be less than the other two approaches because OBM also include loss of $\mathrm{O}_{x}$ due to processes such as heterogeneous loss, dispersion and surface deposition of $\mathrm{O}_{3}$ and $\mathrm{NO}_{2}$. The effect of these processes is expected to be more significant at low production rate of $\mathrm{O}_{x}$, consistent with the feature in Fig. $7 \mathrm{~b}$ that $P\left(\mathrm{O}_{x}\right)$ from OBM starts to become lower than the other two approaches at about 5 ppbv of $\Delta \mathrm{NO}_{x}$.

The agreement of $P\left(\mathrm{O}_{x}\right)$ from Eq. (7) with the 1D model is even better. Given the independent nature of the three methods in evaluating $P\left(\mathrm{O}_{x}\right)$, the good agreement among them provides a strong support for the validity of all three methods. In this context, we need to qualify that the validation applies only to the evaluation of $P\left(\mathrm{O}_{x}\right)$ as a function of consumed $\mathrm{NO}_{x}$. The validation does not necessarily extend to other applications of the three methods.

\subsection{Derivation of $\mathrm{OH}$ concentration}

$\mathrm{OH}$ can be derived from Eq. (5) if the reaction time is known. This OBM-derived $\mathrm{OH}$ can be compared with the model simulated $\mathrm{OH}$. The reaction time is $2 \mathrm{~h}$ (from $9-10$ to $11-12 \mathrm{am}$ ). Fig. 8a depicts values of $\mathrm{OH}$ derived from the $\mathrm{OBM}$ as a function of the average $\mathrm{NO}_{x}$ between 9-10 and 11-12 am, and compared with the $\mathrm{OH}$ from 1D model. Values of $\mathrm{OH}$ by our 1D model are in good agreement with those calculated by
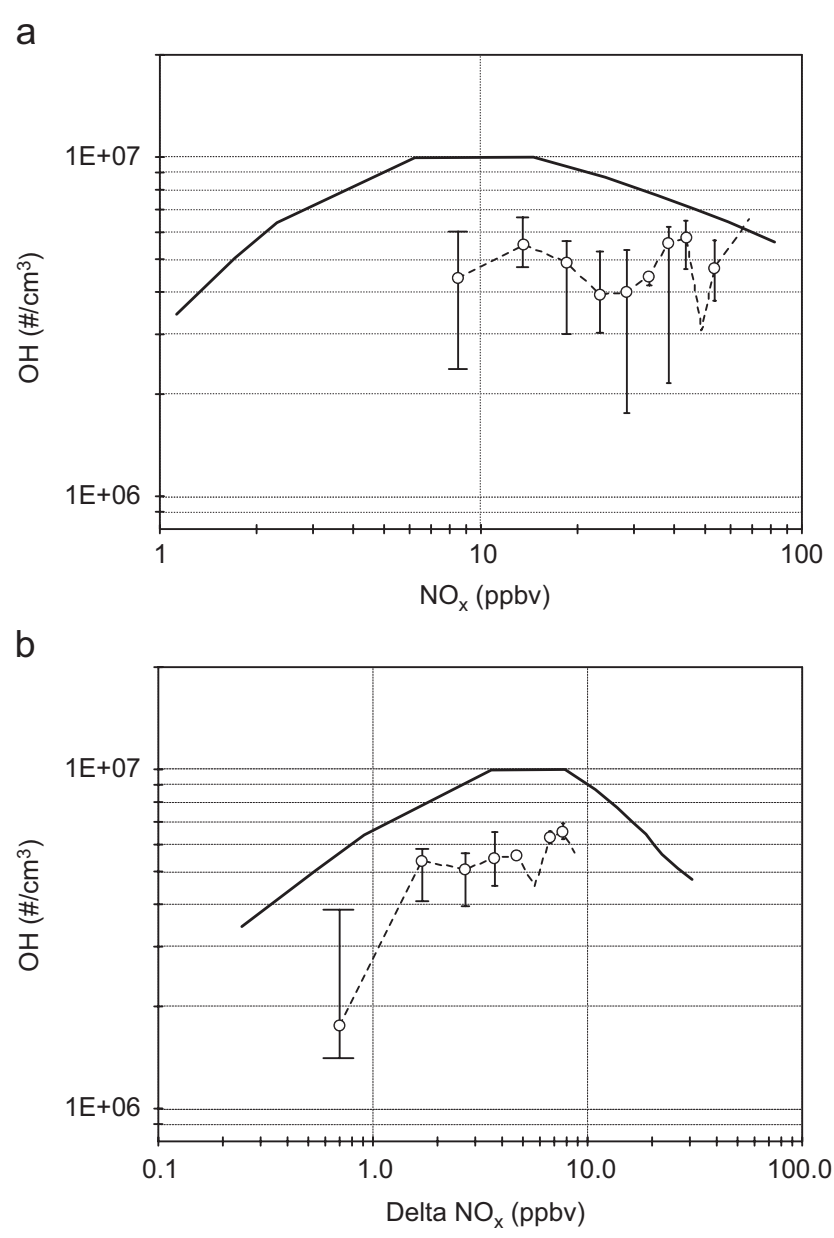

Fig. 8. Similar to Fig. 7 except for $\mathrm{OH}$ concentrations.

McKeen et al. (1997), despite rather different ambient conditions. The OBM-derived $\mathrm{OH}$ concentrations are smaller than model simulated values by a factor of about 2 at $\mathrm{NO}_{x}$ less than 30 ppbv. This is similar to the finding of McKeen et al. (1997). Using $\Delta \mathrm{NO}_{x}$ instead of average $\mathrm{NO}_{x}$ does not improve the discrepancy (Fig. 8b). We have looked into the corresponding distributions of each data points in Fig. $8 \mathrm{~b}$ and found that those OBM-derived $\mathrm{OH}$ values closed to the 1D model curve are mainly from the downwind stations where there are less fresh emissions. Lower values of OBM-derived $\mathrm{OH}$ are from stations located in the Kaohsiung urban center, suggesting that fresh emissions can affect $E / X$ ratio at urban sites (or upwind sites) and lead to the underestimate of $\mathrm{OH}$ values by the OBM.

\subsection{Implications for ozone control strategy}

The results above can be applied to formulating $\mathrm{O}_{3}$ pollution control strategies. Fig. 9 shows 


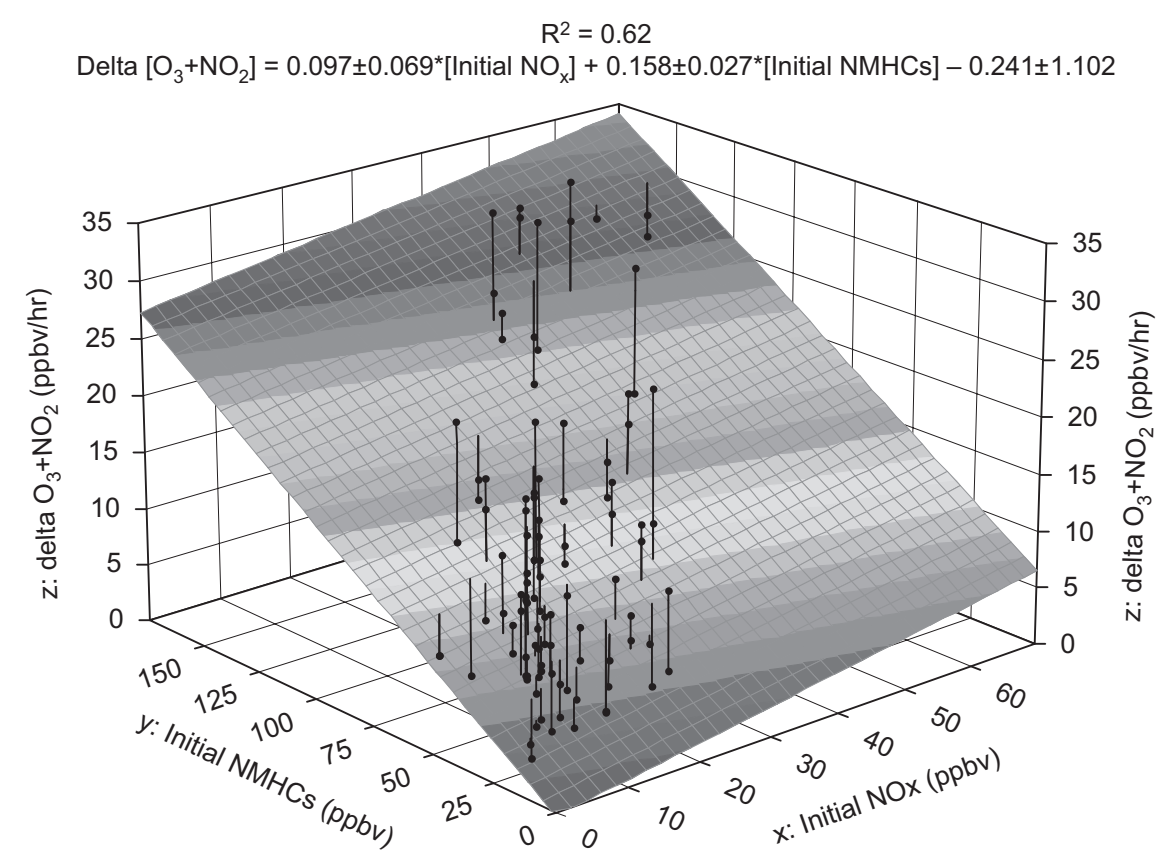

Fig. 9. Total oxidant production rate, i.e. $\Delta\left[\mathrm{O}_{3}+\mathrm{NO}_{2}\right]$ between 10 and 12 am (black dots), are plotted in a three dimensional space as a function of initial concentrations of $\mathrm{NO}_{x}$ and NMHCs. The shaded plane is a linear surface fit to the black dots. The equation listed represents the surface as a function of initial $\mathrm{NO}_{x}$ and NMHCs. $R^{2}$ is the correlation coefficient of the fitting. Lines between the black dots and the plane denote the deviation from the fitting plane.

$\Delta\left[\mathrm{O}_{3}+\mathrm{NO}_{2}\right]$, or $\mathrm{O}_{x}$ production rate, as a function of initial $\mathrm{NO}_{x}$ and initial NMHCs concentrations. $\Delta\left[\mathrm{O}_{3}+\mathrm{NO}_{2}\right]$ is calculated from $\left[\mathrm{O}_{3}+\mathrm{NO}_{2}\right]$ at 11-12 am minus the values at $10-11$ and $9-10 \mathrm{am}$. Similar to the earlier calculation, the initial concentration of $\mathrm{NO}_{x}$ at each site is derived from the consumed $\mathrm{NO}_{x}$ plus the concentration of $\mathrm{NO}_{x}$ observed at 11-12 am. Initial NMHCs are calculated similarly. Consumed $\mathrm{CO}, \mathrm{CH}_{4}$ and isoprene are also taken into account. Also, effects of NMHCs not resolved in the GC are included by multiplying the 56 NMHCs by a factor of 1.5 .

Fig. 9 is similar to the concept of the empirical kinetic modeling approach (EKMA) or $\mathrm{O}_{3}$ isopleth diagrams (e.g. Milford et al., 1989; Gery and Crouse, 1990; Altshuler et al., 1995; Seinfeld and Pandis, 1998), which are intended to relate daily peak $\mathrm{O}_{3}$ levels to initial concentrations of $\mathrm{O}_{3}$ precursors. In fact, Fig. 9 is equivalent to a threedimensional (3D) $\mathrm{OBM} \mathrm{O}_{3}$ production rate isopleth diagram as a function of initial concentrations of $\mathrm{O}_{3}$ precursors. Initial concentrations are used because they are directly proportional to the emissions of $\mathrm{O}_{3}$ precursors.

In order to obtain a simple relationship between the $\mathrm{O}_{x}$ production rate and the precursors of $\mathrm{O}_{3}$, we have made a flat surface (linear) fit to data points of RCEC 2003. Multivariate statistical regression is used to evaluate whether the correlations versus initial $\mathrm{NO}_{x}$ and $\mathrm{NMHCs}$ have statistical significance as separate entities and uncertainty ranges associated with the slopes versus initial $\mathrm{NO}_{x}$ and NMHCs. The correlation coefficient $\left(R^{2}\right)$ for the surface fit is 0.62 . The slopes of $\Delta\left[\mathrm{O}_{3}+\mathrm{NO}_{2}\right]$ versus initial $\mathrm{NO}_{x}$ and NMHCs are $0.097 \pm 0.069$ and $0.158 \pm 0.027$, respectively. The statistical result of $F$ test shows that the regression surface is statistically significant and the value of the slope is significant against initial NMHCs but not significant against initial $\mathrm{NO}_{x}$. This lack of significance can weaken the conclusions in the following interpretation of Fig. 9.

The slightly greater slope against NMHCs suggests that NMHCs are slightly more effective than $\mathrm{NO}_{x}$ in controlling the production rate of the total oxidant. Moreover, because $\mathrm{NO}_{2}$ is a part of the total oxidant $\mathrm{O}_{x}$, reducing $\mathrm{NO}_{x}$ emissions will reduce the titration of $\mathrm{O}_{3}$ and thus increase $\mathrm{O}_{3}$. For example, a $20 \mathrm{ppbv}$ reduction in the initial concentration of $\mathrm{NO}$ would reduce the titration of $\mathrm{O}_{3}$ by $20 \mathrm{ppbv}$, which can be converted to about $5 \mathrm{ppbvh}^{-1}$ of $\mathrm{O}_{3}$ production rate over the morning hours $(\sim 4 \mathrm{~h})$. In comparison the reduction of $\mathrm{O}_{x}$ 
production rate for the $20 \mathrm{ppbv}$ reduction in the initial concentration of $\mathrm{NO}$ is about $0.11 \times 20=$ $2.2 \mathrm{ppbvh}^{-1}$. This means that the production rate of $\mathrm{O}_{3}\left(\right.$ not $\mathrm{O}_{x}$ ) will increase by $2.8 \mathrm{ppbvh}^{-1}$, i.e. $\mathrm{O}_{3}$ concentration will increase when the $\mathrm{NO}_{x}$ initial value is decreased. The effect of titration on $\mathrm{O}_{3}$ in KaoPing is substantiated by an independent study (Chou et al., 2006) on the trends of urban $\mathrm{O}_{3}$ levels in three major metropolitan centers in Taiwan in 1993-2003. They showed that urban $\mathrm{O}_{3}$ levels in Taiwan increased significantly between 1993 and 2003 due to reduced titration by $\mathrm{NO}$ when $\mathrm{NO}_{x}$ emissions were reduced. Fig. 10 illustrates this point for KaoPing area. One can see that nearly $90 \%$ of the increase of $\mathrm{O}_{3}$ in 1993-2003 can be accounted for by the reduction in $\mathrm{NO}_{2}$, i.e. by the reduction of titration. We also use the 1D model to generate a similar surface as the diagram of Fig. 9 (not shown). The slope of $\mathrm{O}_{x}$ against initial NMHCs is more than a factor of three greater than the slope against initial $\mathrm{NO}_{x}$, consistent with the OBM result.

The efficacy of each NMHC for KaoPing area can be found in Chang et al. (2005). Their study suggested that the NMHCs with top $10 \mathrm{O}_{3}$ formation potentials are toluene, ethene, xylene, propene, 1,2,4-trimethylbenzene, styrene, isopentane, isoprene, isobutene and 1-butene.

The balance of evidence suggests that $\mathrm{O}_{3}$ production rate is likely to be NMHCs-sensitive and controlling NMHCs is more efficient than controlling $\mathrm{NO}_{x}$ in reducing urban $\mathrm{O}_{3}$ production. How-

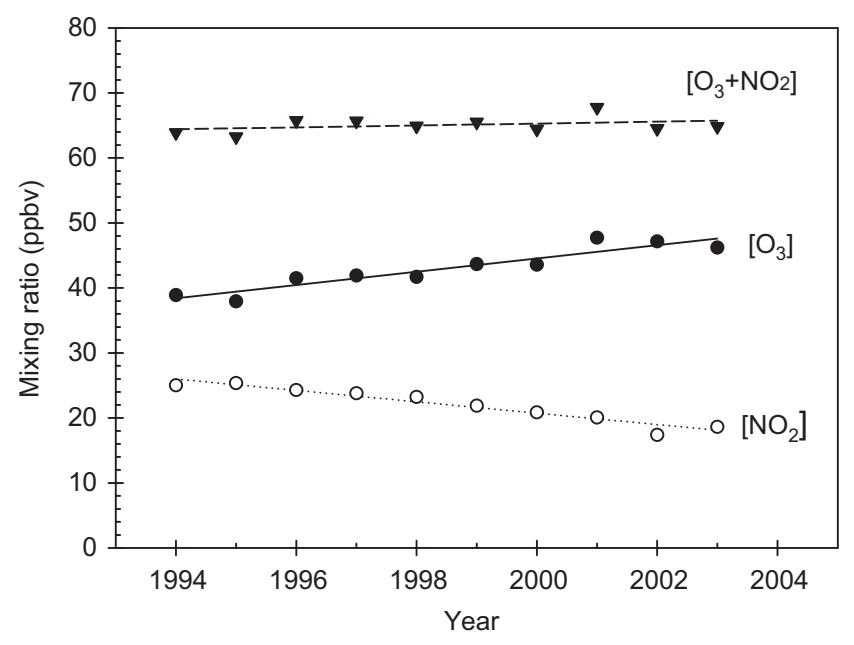

Fig. 10. Trends in the annual average daytime (0900-1800) mixing ratios of $\left[\mathrm{O}_{3}+\mathrm{NO}_{2}\right],\left[\mathrm{O}_{3}\right]$, and $\left[\mathrm{NO}_{2}\right]$ of eight stations in Kaohsiung from 1994 to 2003. Slopes of $\left[\mathrm{O}_{3}+\mathrm{NO}_{2}\right],\left[\mathrm{O}_{3}\right]$, and $\left[\mathrm{NO}_{2}\right]$ are $0.15,1.02$ and $-0.88 \mathrm{ppbv} \mathrm{yr}^{-1}$, respectively. ever, significant uncertainties remain in the OBM, and considerable more work is required to minimize these uncertainties before a definitive control strategy can be reached.

\subsection{Uncertainty of $O B M$}

In this section, we summarize processes and factors that can contribute to the uncertainties or even compromise the conclusions derived by the OBM. The largest source of uncertainty should be fresh emissions, which have been discussed many times above. Fresh emissions exist everywhere all the time. They affect the OBM in various ways, including biasing the $E / X$ toward a smaller value, biasing $\mathrm{NO}_{x}$, NMHCs and $\mathrm{CO}$ toward higher values, but affecting $\mathrm{O}_{x}$ very little. The effect of fresh emissions can become so large that some data have to be filtered out. For example, when the ratio of isobutene to ethane is greater than 0.2 , which indicates fresh emissions, the data points are screened out to reduce the associated bias.

A second source of uncertainty is that $\Delta \mathrm{O}_{x}$ can be affected significantly by entrainment (including advection, dispersion and dilution). The entrainment problem is a major reason we choose to calculate $\Delta \mathrm{O}_{x}$ near the peak $\mathrm{O}_{3}$ production time. As mentioned above, $\Delta \mathrm{O}_{x}$ in the early morning is well known to contain significant $\mathrm{O}_{x}$ entrained from altitude above the mixed layer where high levels of $\mathrm{O}_{x}$ from the previous day often reside. Near peak $\mathrm{O}_{x}$ time both photochemical production and the concentration of $\mathrm{O}_{x}$ are high, thus tend to be less affected by entrainment. On the other hand, entrainment can also dilute $\mathrm{O}_{x}$ or decrease $\Delta \mathrm{O}_{x}$ when the concentration of $\mathrm{O}_{x}$ in the mixed layer is high. Entrainment of other key species such as $\mathrm{NO}_{x}$, NMHCs and $\mathrm{CO}$ can also add to the uncertainty.

Missing NMHCs, i.e. those NMHCs not identified in the measurements, are another source of uncertainty. Although we tried to alleviate the problem as in Fig. 9 by adding to the NMHCs an estimated missing component, the lack of information on the reactivity of the missing NMHCs prevents an accurate estimate of their effect. In addition, oxygenated NMHCs are also not accounted for.

As mentioned in the discussion of Fig. 9, the limited number of measurements contributes significantly to the uncertainty. More measurements can increase the statistic significance and robustness. Moreover, since all the data from 12 stations 
are included in Fig. 9, the OBM cannot distinguish geographic variation, upwind-downwind differences or multi-day $\mathrm{O}_{3}$ production. Lumping data from 12 stations with different ambient environments together certainly add to the scattering of the data and thus the uncertainty. In fact, it is known that a rural downwind station is more likely to be $\mathrm{NO}_{x}$ limited in the $\mathrm{O}_{3}$ production than an urban station (e.g. Blanchard et al., 1999). In this context, more measurements would allow the generation of Fig. 9 for upwind and downwind stations separately and even for individual station, thus reduce the uncertainty of the OBM.

Uncertainties in the measurements of trace species can contribute significantly to the uncertainty of the OBM. In particular, the high detection limit of about 3 ppbv for $\mathrm{NO}_{2}$ (Chou et al., 2006) is of concern, as mixing ratios of $\mathrm{NO}_{2}$ at downwind suburban stations Chaochou and Maynon frequently stay around $5 \mathrm{ppbv}$ in late morning.

Finally, as noted above, $\mathrm{NO}_{x}$ is correlated with NMHCs as the two $\mathrm{O}_{3}$ precursors share a major common source, namely the vehicular emissions. This means that NMHCs and $\mathrm{NO}_{x}$ are not two independent variables, thus tends to weaken the conclusions drawn from Fig. 9.

\section{Summary and conclusions}

An observation-based method (OBM) is developed in this work to study the relationship between the ozone $\left(\mathrm{O}_{3}\right)$ production rate and the precursors of $\mathrm{O}_{3}$ in southern Taiwan. We use the method to estimate the $\mathrm{O}_{3}$ production efficiency and the production rate of $\mathrm{O}_{3}$. A key step in this approach is to use a pair of hydrocarbons, which have a common emission source but different reaction rate constants with $\mathrm{OH}$, namely ethylbenzene and $m, p$ xylene, to study the degree of photochemical activity of $\mathrm{O}_{3}$ production. Another key step in the method is to use the total oxidant $\left(\mathrm{O}_{3}+\mathrm{NO}_{2}\right)$ instead of $\mathrm{O}_{3}$ itself to examine the $\mathrm{O}_{3}$ production because the former has the advantage of staying invariant during the titration process of $\mathrm{O}_{3}$ by $\mathrm{NO}$ and photo-dissociation of $\mathrm{NO}_{2}$, hence the $\left(\mathrm{O}_{3}+\mathrm{NO}_{2}\right)$ concentration responds better than the $\mathrm{O}_{3}$ concentration to the real photochemical production rate of $\mathrm{O}_{3}$. In addition, a one-dimensional (1D) photochemical model has been developed to evaluate the performance of the OBM.

Average $\mathrm{O}_{3}$ production efficiency $(\varepsilon)$ derived by the OBM approach is about 23.5 with 75 percentile of $7.3 \mathrm{~mol} \mathrm{~mol}^{-1}$ at $\mathrm{NO}_{x} \leqslant 10 \mathrm{ppbv}$. It converges to $8.6 \pm 3.5 \mathrm{~mol} \mathrm{~mol}^{-1}$ at $\mathrm{NO}_{x} \gg 20 \mathrm{ppbv}$. These values are in good agreement with the $\mathrm{O}_{3}$ production efficiency calculated from a simple formula developed by Jacob (1999). Values of $\varepsilon$ from the 1D model are slightly smaller than both OBM and Jacob method for $\mathrm{NO}_{x}$ greater than 10 ppbv. But at lower $\mathrm{NO}_{x}$ the OBM values are about two times higher than the 1D model. Results from the three methods imply $\varepsilon$ tends to be greater in rural and suburban conditions than the highly polluted urban conditions, consistent with Liu et al. (1987).

OBM-derived total oxidant production rate, $P\left(\mathrm{O}_{x}\right)$, in KaoPing area ranges from a few to $10 \mathrm{ppbvh}^{-1}$ when $\mathrm{NO}_{x}$ concentration is less than 10 ppbv, and when $\mathrm{NO}_{x}$ concentration is near 30 ppbv, $P\left(\mathrm{O}_{x}\right)$ can be as large as $30 \mathrm{ppbvh}^{-1}$. Values of $P\left(\mathrm{O}_{x}\right)$ from the OBM agree well with those from the $1 \mathrm{D}$ model at $\Delta \mathrm{NO}_{x}$ greater than 3 ppbv. Below 3 ppbv of $\Delta \mathrm{NO}_{x}$, values of $P\left(\mathrm{O}_{x}\right)$ from OBM are about $50 \%$ lower. There are a few points with very low values of $P\left(\mathrm{O}_{x}\right)$ from the OBM, which are mainly due to the influence of fresh emissions. The agreement of $P\left(\mathrm{O}_{x}\right)$ from the Jacob approach with the 1D model is even better. The good agreement among the three independent methods lends a strong support for the validity of our OBM approach. On the other hand, OBMderived concentrations of $\mathrm{OH}$ are smaller than values calculated by the $1 \mathrm{D}$ model by about a factor of 2.

We have developed a three-dimensional (3D) OBM oxidant production rate isopleth diagram that mimics the concept of the EKMA $\mathrm{O}_{3}$ isopleth diagram. The 3D OBM oxidant production rate isopleth diagram (Fig. 9) turns out to be extremely useful for formulating the $\mathrm{O}_{3}$ pollution control strategy. The $3 \mathrm{D} \quad \mathrm{OBM} \mathrm{O} \mathrm{O}_{3}$ production diagram suggests that reducing emissions of NMHCs are more effective in controlling $\mathrm{O}_{3}$ than reducing $\mathrm{NO}_{x}$. However, significant uncertainties remain in the $\mathrm{OBM}$, and considerable more work is required to minimize these uncertainties before a definitive control strategy can be reached.

It is clear that the OBM approach developed in this work is an effective method for studying the relationship between production rate of $\mathrm{O}_{3}$ and its precursors and a powerful tool for formulating control strategies for urban and regional $\mathrm{O}_{3}$ pollution. Finally, the OBM approach is processoriented, it is not location sensitive and can be readily applied to other regions. 


\section{Acknowledgements}

This work was supported, in part, by grants from Academia Sinica under the theme project "Particulate Matter and Its Environmental Impacts in Taiwan" and from the Environment Protection Administration, Taiwan under projects EPA-93FA11-03-D037 and EPA-94-FA11-03-A201 as well as from National Science Council under Projects NSC93-2111-M001-004， NSC94-2111-M001-003 and NSC94-2752-M001-007-PAE. Special thanks are due to Dr. Sasha Madronich of NCAR/ACD in the United State for providing us Tropospheric Ultraviolet \& Visible (TUV) Radiation Model.

\section{References}

Akimoto, H., 2003. Global air quality and pollution. Science 302, 1716-1719.

Altshuler, S.L., Arcado, T.D., Lawson, D.R., 1995. Weekday vs. weekend ambient ozone concentrations: discussion and hypotheses with focus on northern California. Journal of the Air \& Waste Management Association 45 (12), 967-972.

Atkinson, R., 1990. Gas-phase tropospheric chemistry of organic compounds: a review. Atmospheric Environment 24A, 1-42.

Blanchard, C.L., Lurmann, F.W., Roth, P.M., Jeffries, H.E., Korc, M., 1999. The use of ambient data to corroborate analyses of ozone control strategies. Atmospheric Environment 33 (3), 369-381.

Bronnimann, S., Buchmann, B., Wanner, H., 2002. Trends in near-surface ozone concentration in Switzerland: the 1990s. Atmospheric Environment 36 (17), 2841-2852.

Calvert, J.G., 1976. Hydrocarbon involvement in photochemical smog formation in Los Angeles atmosphere. Environmental Science \& Technology 10, 256-262.

Cantrell, C.A., Shetter, R.E., Calvert, J.G., Parrish, D.D., Fehsenfeld, F.C., Goldan, P.D., Kuster, W., Williams, E.J., Westberg, H.H., Allwine, G., Martin, R., 1993. Peroxy radicals as measured in ROSE and estimated from photostationary state deviations. Journal of Geophysical Research 98 (D10), 18355-18366.

Cantrell, C.A., Shetter, R.E., Gilpin, T.M., Calvert, J.G., Eisele, F.L., Tanner, D.J., 1996. Peroxy radical concentrations measured and calculated from trace gas measurements in the Mauna Loa observatory photochemical experiment 2 . Journal of Geophysical Research 101, 14653-14664.

Cardelino, C.A., Chameides, W.L., 2000. The application of data from photochemical assessment monitoring stations to the observation-based model. Atmospheric Environment 34, 2325-2332.

Chang, C.-C., Lo, S.-J., Lo, J.-G., Wang, J.-L., 2003. Analysis of methyl tert-butyl ether (MTBE) in the atmosphere and implications as an exclusive indicator of automobile exhaust. Atmospheric Environment 37, 4747-4755.

Chang, C.-C., Chen, T.-Y., Lin, C.-Y., Yuan, C.-S., Liu, S.C., 2005. Effects of reactive hydrocarbons on ozone formation in southern Taiwan. Atmospheric Environment 39, 2867-2878.
Chang, C.-C., Liu, S.C., Shiu, C.-J., Lai, C.-J., Wang, J.-L., 2007. A concept for estimating consumption of ozone precursors and assessing correlation between oxidant and precursors, submitted for publication.

Chin, M., Jacob, D.J., Munger, J.W., Parrish, D.D., Doddridge, B.G., 1994. Relationship of ozone and carbon monoxide over North America. Journal of Geophysical Research 99 (D7), 14565-14573.

Chou, C.C.-K., Liu, S.C., Lin, C.-Y., Shiu, C.-J., Chang., K.-H., 2006. Trends of ozone and its precursors in Taiwan: implications for ozone control strategies. Atmospheric Environment 40, 3898-3908.

Daum, P.H., Kleinman, D.G., Nunnermacker, Y.-N., Lee, Springston, S.R., Newman, L., Weinstein-Lloyd, J., 2000. Analysis of the processing of Nashville urban emissions on July 3 and July 18, 1995. Journal of Geophysical Research 105 (D7), 9155-9164.

Finlayson-Pitts, B., Pitts, J.N. (Eds.), 2000. Chemistry of the Upper and Lower Atmosphere. Elsevier, New York.

Frost, G.J., et al., 1998. Photochemical ozone production in the rural southeastern United States during the 1990 Rural Oxidants in the Southern Environment (ROSE) program. Journal of Geophysical Research 103, 22,491-22,508.

Gery, M., Crouse, R., 1990. User's Guide for Executing OZIPR, Order No. 9D2196NASA, US Environmental Protection Agency, Research Triangle Park, NC.

Jacob, D.J., 1999. Introduction to Atmospheric Chemistry. Princeton University Press, Princeton, NJ, 266pp.

Jacob, D.J., Logan, J.A., Murti, P.P., 1999. Effect of rising Asian emissions on surface ozone in the United States. Geophysical Research Letters 26, 2175-2178.

Jonson, J.E., Simpson, D., Fagerli, H., Solberg, S., 2005. Can we explain the trends in European ozone levels? Atmospheric Chemistry and Physics Discussions 5, 5957-5985.

Kleinman, L.I., 1986. Photochemical formation of peroxides in the boundary layer. Journal of Geophysical Research 91 (D10), 10889-10904.

Kleinman, L.I., Daum, P.H., Imre, D., Lee, Y.-N., Nunnermacker, L.J., Springston, S.R., Weinstein-Lloyd, J., Rudolph, J., 2002a. Ozone production rate and hydrocarbon reactivity in 5 urban areas: a case of high ozone concentration in Houston. Geophysical Research Letters 29 (10), 1467.

Kleinman, L.I., Daum, P.H., Lee, Y.-N., Nunnermacker, L.J., Springston, S.R., Weinstein-Lloyd, J., Rudolph, J., 2002b. Ozone production efficiency in an urban area. Journal of Geophysical Research 107 (D23), 4733.

Kramp, F., Volz-Thomas, A., 1997. On the budget of $\mathrm{OH}$ radicals and ozone in an urban plume from the decay of C5-C8 hydrocarbons and $\mathrm{NO}_{x}$. Journal of Atmospheric Chemistry 28, 263-282.

Lee, S.H., Akimoto, H., Nakane, H., Kurnosenko, S., Kinjo, Y., 1998. Lower tropospheric ozone trend observed in 1989-1997 at Okinawa, Japan. Geophysical Research Letters 25 (10), 1637-1640.

Lelieveld, J., van Aardenne, J., Fischer, H., de Reus, M., Williams, J., Winkler, P., 2004. Increasing ozone over the Atlantic Ocean. Science 304, 1483-1487.

Levy II, H., Mahlman, J.D., Moxim, W.J., Liu, S.C., 1985. Tropospheric ozone: the role of transport. Journal of Geophysical Research 90 (D2), 3753-3772. 
Lin, C.-Y.C., Jacob, D.J., Munger, J.W., Fiore, A.M., 2000. Increasing background ozone in surface air over the United States. Geophysical Research Letters 27, 3465-3468.

Liu, S.C., 1977. Possible effects on tropospheric $\mathrm{O}_{3}$ and $\mathrm{OH}$ due to NO emission. Geophysical Research Letters 4, 325-328.

Liu, S.C., Trainer, M., Fehsenfeld, F.C., Parrish, D.D., Williams, E.J., Fahey, D.W., Hukbler, G., Murphy, P.C., 1987. Ozone production in the rural troposphere and the implications for regional and global ozone distributions. Journal of Geophysical Research 92 (D4), 4191-4207.

Logan, J.A., 1989. Ozone in rural areas of the United States. Journal of Geophysical Research 94, 8511-8532.

Logan, J.A., Prather, M.J., Wofsy, S.C., Mcelroy, M.B., 1981. Tropospheric chemistry - a global perspective. Journal of Geophysical Research (D86), 7210-7254.

Madronich, S., Flocke, S., 1998. The role of solar radiation in atmospheric chemistry. In: Boule, P. (Ed.), Handbook of Environmental Chemistry. Springer, Heidelberg, pp. 1-26.

McKeen, S.A., Liu, S.C., 1993. Hydrocarbon ratios and photochemical history of air masses. Geophysical Research Letter 20, 2363-2366.

Mckeen, S.A., Mount, G., Eisele, F., Williams, E., Harder, J., Goldan, P., Kuster, W., Liu, S.C., Baumann, K., Tanner, D., Fried, S., Sewell, C., Cantrell, C., Shetter, R., 1997. Photochemical modeling of hydroxyl and its relationship to other species during the tropospheric $\mathrm{OH}$ photochemistry experiment. Journal of Geophysical Research 102, 6467-6493.

Mihelcic, D., et al., 2003. Peroxy radicals during Berlioz at Pabstthum: measurements, radical budgets and ozone production. Journal of Geophysical Research 108 (D4), 8254.

Milford, J.B., Russell, A.G., McRae, G.J., 1989. A new approach to photochemical pollution control: implications of spatial patterns in pollutant responses to reductions in nitrogen oxides and reactive organic gas emissions. Environmental Science \& Technology 23, 1290-1301.

Molina, M.J., Molina, L.T. (Eds.), 2002. Air Quality in the Mexico Megacity: An Integrated Assessment. Springer, New York.

Nunnermacker, L.J., Imre, D., Daum, P.H., Kleinman, L., Lee, Y.-N., Lee, J.H., Springston, S.R., Newman, L., WeinsteinLloyd, J., Luke, W.T., Banta, R., Alvarez, R., Senff, C., Sillman, S., Holdren, M., Keigley, G.W., Zhou, X., 1998. Characterization of the Nashville urban plume on July 3 and July 18, 1995. Journal of Geophysical Research 103 (D21), 28129-28148.

Olszyna, J.K., Bailey, E.M., Simonaitis, R., Meagher, J.F., 1994. $\mathrm{O} 3$ and $\mathrm{NO}_{y}$ relationship at a rural site. Journal of Geophysical Research 99 (D7), 14557-14563.

Oltmans, S.J., Lefohn, A.S., Scheel, H.E., Harris, J.M., Levy II, H., Galbally, I.E., Brunke, E.-G., Meyer, C.P., Lathrop, J.A., Johnson, B.J., Shadwick, D.S., Cuevas, E., Schmidlin, F.J., Tarasick, D.W., Claude, H., Kerr, J.B., Uchino, O., Mohnen, V., 1998. Trends of ozone in the troposphere. Geophysical Research Letters 25 (2), 139-142.

Parrish, D.D., Trainer, M., Williams, E.J., Fahey, D.W., HuK bler, G., Eubank, C.S., Liu, S.C., Murphy, P.C., Albritton, D.L., Fehsenfeld, F.C., 1986. Measurements of the $\mathrm{NO}_{x}-\mathrm{O}_{3}$ photostationary state at Niwot Ridge, Colorado. Journal of Geophysical Research 91, 5361-5370.

Parrish, D.D., Hahn, C.J., Williams, E.J., Norton, R.B., Fehsenfeld, F.C., Singh, H.B., Shetter, J.D., Gandrud,
B.W., Ridley, B.A., 1992. Indications of photochemical histories of Pacific air masses from measurements of atmospheric trace species at Point Arena, California. Journal of Geophysical Research 97, 15833-15901.

Parrish, D.D., et al., 2004. Changes in the photochemical environment of the temperate North Pacific troposphere in response to increased Asian emissions. Journal of Geophysical Research 109, D23S18.

Robert, J.M., Fehsenfeld, F.C., Liu, S.C., Bollinger, M.J., Hahn, C., Albritton, D.L., Sievers, R.E., 1984. Measurements of aromatic hydrocarbon ratios and $\mathrm{No}_{x}$ concentrations in the rural troposphere: observation of air mass photochemical aging and $\mathrm{NO}_{x}$ removal. Atmospheric Environment 18 (11), 2421-2432.

Ryerson, T.B., Buhr, M.P., Frost, G.J., Goldan, P.D., Holloway, J.S., Hübler, G., Jobson, B.T., Kuster, W.C., Mckeen, S.A., Parrish, D.D., Roberts, J.M., Sueper, D.T., Trainer, M., Williams, J., Fehsenfeld, F.C., 1998. Emissions lifetimes and ozone formation in power plant plumes. Journal of Geophysical Research 103 (D17), 22569-22583.

Sander, S.P., Friedl, R.R., Ravishankara, A.R., Golden, D.M., Kolb, C.E., Kurylo, M.J., Huie, R.E., Orkin, V.L., Molina, M.J., Moortgat, G.K., Finlayson-Pitts, B.J., 2002. Chemical Kinetics and Photochemical Data for Use in Atmospheric Studies Evaluation Number 14, JPL Publication 02-25.

Seinfeld, J.H., Pandis, S.N., 1998. Atmospheric Chemistry and Physics from Air Pollution to Climate Change. Wiley, New York, 1326pp.

Sillman, S., 1999. The relation between ozone, $\mathrm{NO}_{x}$, and hydrocarbons in urban and polluted rural environments. Atmospheric Environment 33, 1821-1845.

Sillman, S., He, D., Pippin, M., Daum, P., Kleinman, L., Lee, J.H., Weinstein-Lloyd, J., 1998. Model correlations for ozone, reactive nitrogen and peroxides for Nashville in comparison with measurements: implications for $\mathrm{O}_{3}-\mathrm{NO}_{x}$-hydrocarbon chemistry. Journal of Geophysical Research 103 (D17), 22629-22644.

Singh, H.B., 1977. Atmospheric halocarbons: evidence in favor of reduced average hydroxyl radical concentration in the troposphere. Geophysical Research Letters 4, 101-104.

Trainer, M., Hsie, E.Y., Mckeen, S.A., Tallamaju, R., Parrish, D.D., Fehsenfeld, F.C., Liu, S.C., 1987. Impact of natural hydrocarbons on hydroxyl and peroxy radicals at a remote site. Journal of Geophysical Research 92 (D10), 11879-11894.

Trainer, M., et al., 1991. Observations and modeling of the reactive nitrogen photochemistry at a rural site. Journal of Geophysical Research 96, 3045-3063.

Trainer, M., Parrish, D.D., Buhr, M.P., Norton, R.B., Fehsenfeld, F.C., Anlauf, K.G., Bottenheim, J.W., Tang, Y.Z., Weibe, H.A., Roberts, J.M., Tanner, R.L., Newman, L., Bowersox, V.C., Meagher, J.T., Olszyna, K.J., Rodgers, M.O., Wang, T., Berresheim, H., Demerjian, K.L., Roychowdhury, U.K., 1993. Correlation of ozone with $\mathrm{NO}_{y}$ in photochemically aged air. Journal of Geophysical Research 98 (D2), 2917-2925.

Trainer, M., Ridley, B.A., Buhr, M.P., Kok, G., Walega, J., Hübler, G., Parrish, D.D., Fehsenfeld, F.C., 1995. Regional ozone and urban plumes in the southeastern United States: Birmingham, a case study. Journal of Geophysical Research 100 (D9), 18823-18834.

Trainer, M., Parrish, D.D., Goldan, P.D., Roberts, J., Fehsenfeld, F.C., 2000. Review of observation-based analysis of the 
regional factors influencing ozone concentrations. Atmospheric Environment 34, 2045-2061.

Wang, Y.-H., Liu, S.C., Yu, H.-B., Sandholm, S.T., Chen, T.Y., Blake, D.R., 2000. Influence of convection and biomass burning outflow on tropospheric chemistry over the tropical Pacific. Journal of Geophysical Research 105 (D7), 9321-9333.
Zaveri, R.A., Berkowitz, C.M., Kleinman, L., Springston, S.R., Doskey, P.V., Lonneman, W.A., Spicer, C.W., 2003. Ozone production efficiency and $\mathrm{NO}_{x}$ depletion in an urban plume: Interpretation of field observations and implications for evaluating $\mathrm{O}_{3}-\mathrm{NO}_{x}-$ VOC sensitivity. Journal of Geophysical Research 108 (D14), 4436. 